\title{
New insights into the degassing dynamics of Lago Albano (Colli Albani volcano, Rome, Italy) during the last three decades (1989-2019)
}

\author{
Dmitri Rouwet (1), Giancarlo Tamburello (1), Giovanni Chiodini (1), Giovannella Pecoraino (2), \\ Monia Procesi (3), Tullio Ricci (3), Stefania Venturi $(4,5)$, Alessandro Santi (4), Jacopo Cabassi (5), \\ Orlando Vaselli $(4,5)$, Franco Tassi $(4,5)$ \& Antonio Costa (1)
}

\section{ABSTRACT}

With this study a nine-year hiatus (May 2010-April 2019) in the quantification of the $\mathrm{CO}_{2}$ content of Lago Albano by our working group has been resolved through the acquisition and analysis from two new field campaigns. Based on a $\mathrm{CO}_{2}$ budget analysis the dynamics of $\mathrm{CO}_{2}$ degassing throughout the past thirty years $(1989-2019)$ is detailed and quantified. The decreasing $\mathrm{CO}_{2}$ content (expressed as dissolved inorganic carbon, DIC) in the lake, since the co-seismic $\mathrm{CO}_{2}$ input during the 1989-1990 seismic swarm beneath Colli Albani volcano, was accelerated at lake bottom layers $(-140 \mathrm{~m}$ to bottom, near $-160 \mathrm{~m})$ in the 4-5 years after the swarm, continued afterwards at lower depths (-125 to $-95 \mathrm{~m}$ ), and seems to have reached steady-state conditions during recent years. The peculiar lake basin morphology has control on the degassing dynamics. The low chemical gradients detected during the April 2019 survey have induced near-zero degassing conditions, and arguably stopped the gas-self lifting process: Lago Albano might not become $\mathrm{CO}_{2}$-free in the future. This finding has implications for gas hazard when the next seismic swarm will hit the area. The updated degassing model also takes into account the lake level drop, and hence the volume decrease of Lago Albano, caused by excessive well pumping for anthropic purposes. This volume decrease appears to have a destabilizing effect on the degassing dynamics, which renders Lago Albano's gas release less predictable in the future. Enhanced gas surveys (high-frequency and fine-scale spatial measurements) are needed to shed light on how Lago Albano degasses in this quiescent stage during the Anthropocene. A submersible infra-red detector to directly measure in-lake dissolved $\mathrm{CO}_{2}$ concentrations, applied satisfactorily during this study, is an adapted instrument to do so.

KEY WoRDs: volcanic lake, degassing dynamics, dissolved $\mathrm{CO}_{2}$, lake stability, limnology, hazard assessment.

\section{INTRODUCTION}

After the deadly Lake Nyos gas burst in August 1986 in Cameroon (KLING et alii, 1987; TANYILEKE et alii, 2019) Lago Albano, on the border of Colli Albani volcanic complex (e.g. GioRDANo et alii, 2006), became the focus of several studies aimed at investigating its $\mathrm{CO}_{2}$ degassing

(1) Istituto Nazionale di Geofisica e Vulcanologia, Sezione di Bologna, Italy.

(2) Istituto Nazionale di Geofisica e Vulcanologia, Sezione di Palermo, Italy.

(3) Istituto Nazionale di Geofisica e Vulcanologia, Sezione di Roma1, Italy.

(4) University of Florence, Department of Earth Sciences, Florence, Italy.

(5) Istituto di Geoscienze e Georisorse, Consiglio Nazionale delle Ricerche (CNR-IGG), Florence, Italy.

Corresponding author e-mail: dmitri.rouwet@ingv.it dynamics in the late eighties-early nineties (IWGCL Newsletter; Martini et alii, 1994; PEDRESCHI, 1995). In 19891990, a seismic swarm beneath Colli Albani resulted in the injection of a significant amount of $\mathrm{CO}_{2}$ into Lago Albano's deepest water layers (АмATO et alii., 1994; CARAPEZZA et alii, 2008, Chiodins et alii, 2012). These two almost synchronous events warned about the potential hazard assessment of Europe's deepest volcanic lake, similar to Lake Nyos (i.e. "Nyos-bias", Rouwet et alii, 2019). Nevertheless, the sudden seismically triggered $\mathrm{CO}_{2}$ recharge below Lago Albano in 1989-1990 did not turn out to be sufficiently voluminous to cause $\mathrm{CO}_{2}$ supersaturation of the bottom waters and consequent sudden gas release. Moreover, it is known that temperate climates protect volcanic lakes from accumulating $\mathrm{CO}_{2}$ for prolonged periods, as yearly lake turnover facilitates partial $\mathrm{CO}_{2}$ release in winter when cold, dense $\mathrm{CO}_{2}$-free surface waters sink into deeper water layers (CHIODINI et alii, 2012). Rouwet et alii (2019) proposed that Lago Albano is instead an "anti-Nyos-type" lake, for being suddenly recharged with $\mathrm{CO}_{2}$ (vs. a continuous $\mathrm{CO}_{2}$ input at Lake Nyos; Evans et alii, 1993; KuSAKABE, 2017), and with a periodical $\mathrm{CO}_{2}$ release during winter overturn events (vs. sudden gas bursts at Lake Nyos following $\mathrm{CO}_{2}$ saturation; KUSAKABE, 2015, 2017).

The recent review of anomalous $\mathrm{CO}_{2}$ degassing related to six seismic crises during the $19^{\text {th }}$ and $20^{\text {th }}$ centuries near Colli Albani has demonstrated that three out of six crises led to anomalous degassing, regardless of the magnitude and duration of the seismic crisis (Rouwet et alii, 2019). In terms of hazard, $\mathrm{CO}_{2}$ can suddenly be released from Lago Albano during seismic crises (1) when near-critical $\mathrm{CO}_{2}$ concentrations dominate in deep water layers, or (2) when well-localized vents massively inject $\mathrm{CO}_{2}$ into the lake to punch through any physical-chemical lake stratification. It is hence of great importance to monitor the $\mathrm{CO}_{2}$ saturation state of deep layers since a seismic crisis can occur at any time.

Within these perspectives, this study provides a new data set on water and dissolved gas chemistry (chemical and isotopic composition $-\delta^{13} \mathrm{C}_{\mathrm{DIC}}, \delta^{13} \mathrm{C}_{\mathrm{CO} 2}, \delta^{13} \mathrm{C}_{\mathrm{CH}}{ }^{3} \mathrm{He} /{ }^{4} \mathrm{He}$ ratios), and physicochemical parameters along a vertical profile in correspondence with the maximum depth of Lago Albano for April and June 2019. These measurements, which in the past were routinely acquired (CIONI et alii, 2003; CARAPEZZA et alii, 2008), are the first publicly available since May 2010, after an hiatus of almost nine years since 
the last published monitoring results (CHIODINI et alii, 2012). Results of direct measurements of dissolved $\mathrm{CO}_{2}$ with a submersible infra-red detector were compared to the $\mathrm{CO}_{2}$ contents measured in directly sampled gases, to verify the usefulness of faster and in-situ probe measurements. We aim at updating the degassing model proposed by CHIOdini et alii (2012), in the aftermath of the 2016-2017 tectonic earthquakes in Central Italy. Forecasts in terms of hazard assessment for the near and far future are critically proposed.

\section{THE VOLCANIC LAKE, LAGO ALBANO}

Lago Albano is a $3.36 \times 2.28 \mathrm{~km}, 160-167 \mathrm{~m}$ deep polygenetic maar lake (volume $=4.48 \times 10^{8} \mathrm{~m}^{3}$ ), consisting of five coalescent and partially overlapping craters that were formed by phreatomagmatic activity, being the most active center of the currently quiescent Colli Albani volcanic complex (FREDA et alii, 2006; GIORDANO et alii, 2006; ANZIDEI et alii, 2008; MARRA et alii, 2020) (Fig. 1). The major axis of Lago Albano is NW-SE oriented, and the lake fills the largest of three basins formed by phreatomagmatic activity in the western parts of the horseshoe-shaped Colli Albani caldera opened to the west. The depth ratio (DR) for Lago Albano, as reported by Rouwet et alii (2019), is:

$\mathrm{DR}=(\mathrm{V} / \mathrm{S}) / \mathrm{d}_{\max }=0.45$

where $\mathrm{d}_{\max }$ is the maximum lake depth (in $\mathrm{m}$ ), $\mathrm{S}$ is the surface area (in $\mathrm{m}^{2}$ ), and $\mathrm{V}$ is the lake volume (in $\mathrm{m}^{3}$, from ANZIDEI et alii, 2008). The lake water level of Lago Albano was affected by significant changes during the historical past (Rouwet et alii, 2019, and references therein). In 398 BC, a sharp water rise was described by the Roman historian Livy, possibly due to a rollover event caused by the injection through the lake bottom of volcanic gas-rich hot fluids (Funiciello et alii, 2003; ANZIDEI et alii, 2008). The presence and origin of the tunnel that drains the lake since antiquity is still a matter of debate (FunICIELLo et alii, 2003; Rouwet et alii, 2019). Volcanologists possibly over-interpreted the tunnel, being considered a mitigation
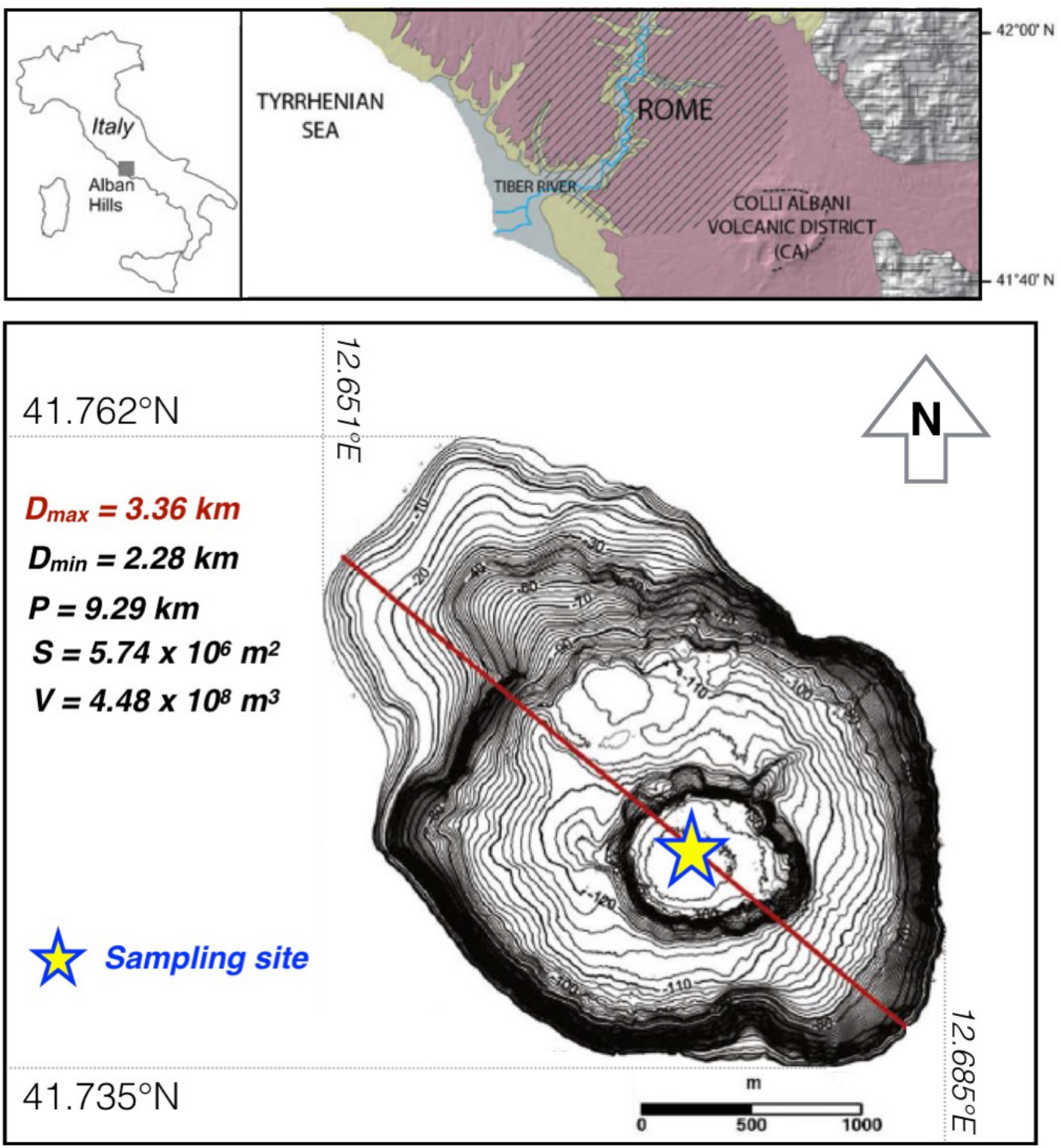

Fig. 1 - Location maps of the Colli Albani Volcanic District (CA) in Italy and with respect to Rome (modified from MARRA et alii, 2020), and bathymetric map of Lago Albano, showing the main features and quantification of morphological parameters: $\mathrm{D}_{\text {max }}$ $=$ maximum diameter, $\mathrm{D}_{\min } \stackrel{\mathrm{m}_{\max }}{=}$ minimum diameter (perpendicular to $\mathrm{D} \quad$ ), $\mathrm{P}=$ perimeter, $\mathrm{S}=$ surface area, ${ }^{\operatorname{Vax}}=$ lake volume (from Anzidei et alii, 2008). The yellow star indicates the approximate April and June 2019 sampling and measurement site. 
measure to avoid future sudden lake outflow, in the aftermath of the Lake Nyos lethal gas burst (i.e. "Nyosbias"). Two main hypotheses can be formulated: (1) the tunnel was built by the Romans to keep the lake level constant at about $293 \mathrm{~m}$ a.s.l. after $398 \mathrm{BC}$ to mitigate future risk, or (2) the Etruscans built the tunnel before the Romans to irrigate the low-lying fields in the Ciampino Plain (see Rouwet et alii, 2019, for a detailed review and discussion).

Moreover, Lago di Nemi $(1.86 \times 1.30 \mathrm{~km}, 32 \mathrm{~m}$ deep) lays on the southwestern inner slopes of the Colli Albani caldera with a NNE-SSW orientation. The Ariccia Plain, another phreatomagmatic crater structure west of Lago di Nemi, is not hosting a lake. Anomalous diffuse $\mathrm{CO}_{2}$ degassing in the surrounding areas occurs at Cava dei Selci (5 km NW of Lago Albano, at the Ciampino Plain lahar deposits) and Acqua Acetosa (NE shore of Lago Albano itself) (Chiodini \& Frondini, 2001; Funiciello et alii, 2002; CARAPEZza et alii, 2003; VENTURI et alii, 2019).

\section{IN-SITU MEASUREMENTS, SAMPLING AND ANALYTICAL PROCEDURES}

On the $16^{\text {th }}$ of April, 2019, water depth (m), temperature $\left({ }^{\circ} \mathrm{C}\right), \mathrm{pH}$, dissolved oxygen $\left(\mathrm{O}_{2}\right.$ in $\left.\mu \mathrm{mol} / \mathrm{L}\right)$, and electrical conductivity $\left(\mathrm{mS} / \mathrm{cm}\right.$ at $\left.20{ }^{\circ} \mathrm{C}\right)$ were measured along a vertical profile at the deepest point of Lago Albano using a multiparametric probe (Idromarambiente SCRL IP-188A) equipped with a data logger for data storage. Precisions of the measurements were $\pm 0.05 \mathrm{~m}, \pm 0.03{ }^{\circ} \mathrm{C}, \pm 0.1 \mathrm{pH}$ units, $\pm 1.56 \mu \mathrm{mol} / \mathrm{L}$, and $\pm 0.01 \mathrm{mS} / \mathrm{cm}$, respectively (CHIODINI et alii, 2012; CABASSI et alii, 2019).

In April and June 2019, an infra-red ProOceanus Mini- $\mathrm{CO}_{2}$ probe (https://pro-oceanus.com/) was lowered overboard along the vertical profile at the deepest portion of Lago Albano. The $\mathrm{CO}_{2}$ measurement range of the probe was $0-1 \%(0-10,000 \mu \mathrm{atm})$, with an accuracy of $\pm 2 \%$ of the maximum range, an equilibration rate of 3 minutes, and a sample rate of $0.5 \mathrm{~Hz}$. Laboratory experiments, before field application, demonstrated a longer ideal response time of at least 10 minutes (the time required to reach a stable measurement plateau); therefore, the probe was left at fixed depths $(0,-20,-40,-60,-80,-100,-120,-140 \mathrm{~m})$ for approximately 20 minutes. The excellent instrumental response of the ProOceanus Mini- $\mathrm{CO}_{2}$ probe was reflected by a standard deviation of the $\mathrm{CO}_{2}$ concentration of the inlake measurements between 0.014 and $0.067 \%$.

To assure inter-comparison with earlier studies and probe measurements, water and dissolved gases were sampled at $10 \mathrm{~m}$ intervals above the deepest point of Lago Albano. Rilsan ${ }^{\circledR}$ tubes were lowered to the desired lake depth and water and its dissolved gases were pumped up after abundant rinsing of the tubing (CHIODINI et alii, 2012; TAssi \& Rouwet, 2014). The water temperature was taken from probe measurements, as pumping up the water through the Rilsan ${ }^{\circledR}$ tubes causes water heating through friction. The $\mathrm{pH}$ was measured using a portable instrument (Hanna Instruments) with an accuracy of \pm 0.1 .

Water samples were filtered $(0.22 \mu \mathrm{m})$ before storage in HDPE Falcon flasks (anion analyses). Duplicates were acidified for cation analyses. Major cation and anion composition of waters $\left(\mathrm{Na}^{+}, \mathrm{K}^{+}, \mathrm{Ca}^{2+}, \mathrm{Mg}^{2+}, \mathrm{Cl}^{-}, \mathrm{SO}_{4}^{2-}\right)$ were determined by ion chromatography at INGV-Sezione di
Palermo, using a DIONEX DX 120 ion chromatograph. A Dionex CS-12A column was used for the cations and a Dionex AS14A column for anion determinations. Alkalinity was measured by acidimetric titration in the lab with $\mathrm{HCl}$ $0.01 \mathrm{~N}$. The electroneutrality parameter was $<5.7 \%$.

Dissolved gases were collected as water samples in preevacuated and pre-weighed $250 \mathrm{ml}$ glass flasks with twoway glass valves, leaving a headspace of approximately $20 \%$ of the total flask volume (CHIODINI, 1996; CALIRo et alii, 2008; TAssI et alii, 2009). $\mathrm{CO}_{2}, \mathrm{~N}_{2}, \mathrm{O}_{2}$, and $\mathrm{Ar}$ in the flask headspace were analyzed by gas chromatography (University of Florence) using a Shimadzu 15A gaschromatograph equipped with a thermal conductivity detector (TCD). Methane concentrations were measured by a Shimadzu 14A gas chromatograph equipped with a Flame Ionization Detector (FID). The total chemical composition of gases was calculated based on Henry's law constants, establishing liquid-gas equilibrium conditions for each gas species.

The carbon isotopes (expressed as $\delta^{13} \mathrm{C}$ for $\mathrm{CO}_{2}$ and $\mathrm{CH}_{4}$ in \%o vs. V-PDB) were determined using a Picarro G2201-i CRDS analyser (University of Florence) on the gas collected in the headspace of the sampling flask (analytical error: 0.16 and $1.15 \%$, respectively). The carbon isotopic composition of total dissolved inorganic carbon (expressed as $\delta^{13} \mathrm{C}_{\mathrm{DIC}}$ in \%o vs. V-PDB) was analyzed with a Finnigan Delta Plus mass spectrometer on $\mathrm{CO}_{2}$, accumulated in the headspace of a glass flask and in equilibrium with the water sample, obtained by transferring $2-4 \mathrm{~mL}$ of water to the $12 \mathrm{~mL}$ pre-evacuated glass flask where $2 \mathrm{~mL}$ of anhydrous $\mathrm{H}_{3} \mathrm{PO}_{4}$ were added to lower the $\mathrm{pH}$. Before the analysis, $\mathrm{CO}_{2}$ was purified with two cryogenic traps (INGV-Sezione di Palermo, with an accuracy of $\pm 0.15 \%$; CAPAsso et alii, 2005).

The helium isotopic ratios ${ }^{3} \mathrm{He} /{ }^{4} \mathrm{He}$ were measured in the water samples collected at 140 and $150 \mathrm{~m}$ depth and at the lake bottom (near $155 \mathrm{~m}$ ) at INGV-Sezione di Palermo, according to the method proposed by InguagGiato \& Rizzo (2004). The abundance and isotopic composition of He, and the ${ }^{4} \mathrm{He} /{ }^{20} \mathrm{Ne}$ ratios, were determined by separately admitting $\mathrm{He}$ and $\mathrm{Ne}$ into a split flight tube mass spectrometer (Helix SFT). Helium isotopic compositions are expressed as $R / R_{A}$, where $\mathrm{R}$ is the ${ }^{3} \mathrm{He} /{ }^{4} \mathrm{He}$ ratio of the sample and $R_{A}$ is the atmospheric ${ }^{3} \mathrm{He} /{ }^{4} \mathrm{He}$ ratio $\left(\mathrm{R}_{\mathrm{A}}=1.386\right.$ $\left.\times 10^{-6}\right)$. The analytical error was generally $<1 \%$. The ${ }^{4} \mathrm{He} /{ }^{20} \mathrm{Ne}$ ratio was used to correct measured values for the atmospheric contamination $\left(\mathrm{R}_{\mathrm{C}} / \mathrm{R}_{\mathrm{A}}\right.$; SANO \& WAKITA, 1985).

\section{RESULTS AND DISCUSSION}

\section{PHYSICOCHEMICAL PARAMETERS AND LIMNOLOGY}

The vertical profiles of the physicochemical parameters - temperature, pH, electrical conductivity, and dissolved oxygen content - are presented in Fig. 2. As observed in previous surveys (CIONI et alii, 2003; CARAPEZZA et alii, 2008; Chiodini et alii, 2012; CABASsi et alii, 2013), Lago Albano was also clearly stratified in April 2019 with (1) an atmospherically heated epilimnion with temperatures varying between $13.2^{\circ} \mathrm{C}$ and $9.9^{\circ} \mathrm{C}, \mathrm{pH}$ values from 9.17 to 8.56 , electrical conductivities from 0.41 to $0.37 \mathrm{mS} / \mathrm{cm}$, and an $\mathrm{O} \%$ with respect to saturation ranging from $100 \%$ (at the lake surface) to $50 \%$ (at $20 \mathrm{~m}$ depth); (2) an intermediate 


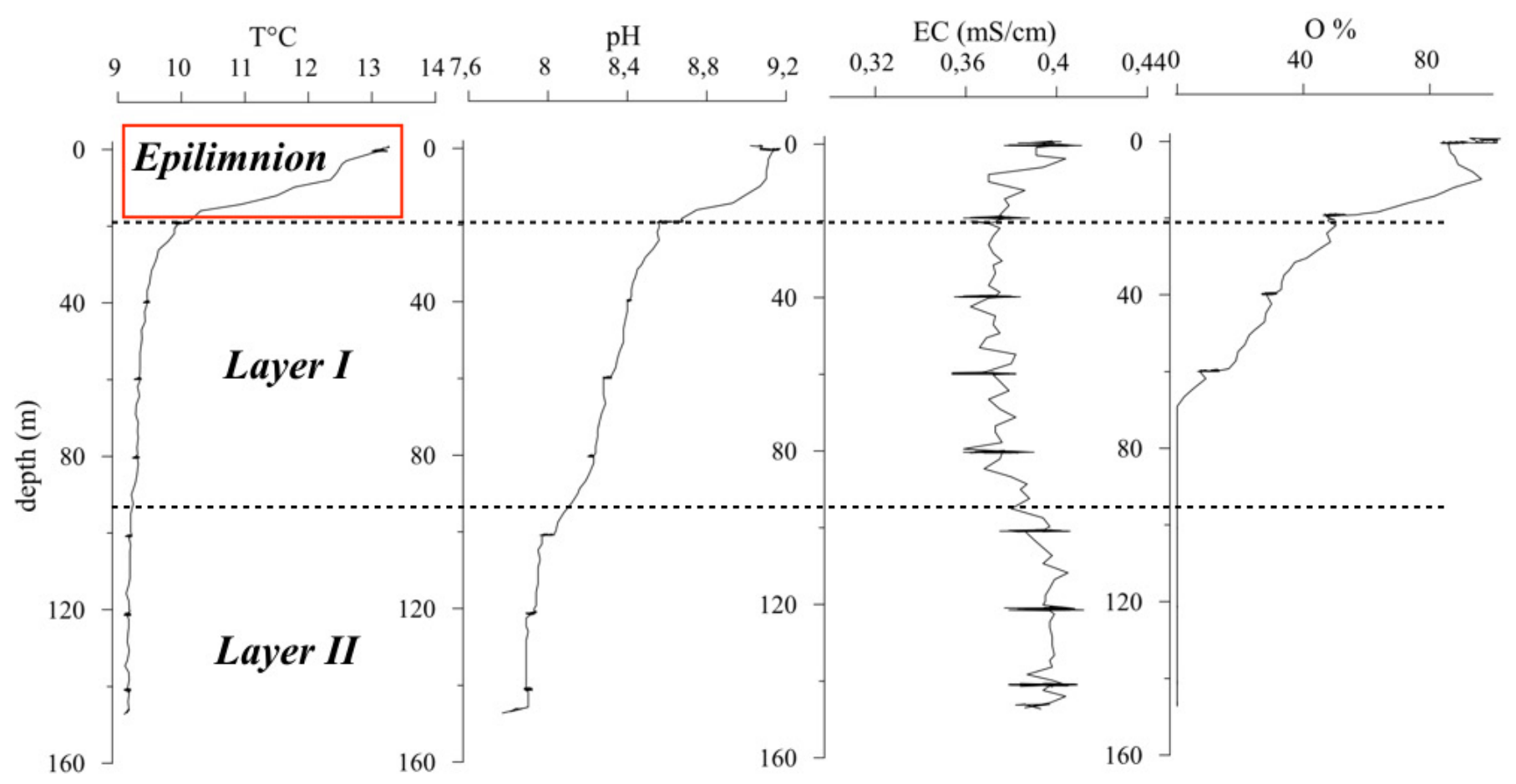

Fig. 2 - Physicochemical parameters $\mathrm{T}\left({ }^{\circ} \mathrm{C}\right)$, pH, Electrical Conductivity $(\mathrm{EC})$ and oxygen $\%(\mathrm{O} \%)$ as measured with the $\mathrm{CTD}$ probe on 16 April 2019. Dotted lines indicate the clines dividing the various layers. The horizontal variations, especially visible for EC, are a measure of the natural variability and instrumental accuracy when the probe is left at a fixed depth for approximately 20 minutes. The small but sharp drop in pH at the bottom probably reflects the $\mathrm{CO}_{2}$ accumulation in bottom sediments. The red square indicates the zoomed area of Fig. 3 .

layer (-20 to $-95 \mathrm{~m}$, called Layer I by CHIODINI et alii, 2012) showing a temperature decrease from $9.9{ }^{\circ} \mathrm{C}$ to $9.2{ }^{\circ} \mathrm{C}$, a drop in $\mathrm{pH}$ from 8.56 to 8.08 , and a very slight increase in electrical conductivity (from 0.37 to $0.39 \mathrm{mS} / \mathrm{cm}$ ). The water became anoxic at $-69 \mathrm{~m}$; (3) a deep layer (-95 to bottom at -167 $\mathrm{m}$, called Layer II by CHIODINI et alii, 2012) with a constant low temperature (9.1-9.2 ${ }^{\circ} \mathrm{C}$ ), an additional $\mathrm{pH}$ decrease from 8.08 to 7.7 (at $-146 \mathrm{~m}$, the deepest point measured in our survey), and a stable electrical conductivity of 0.39 $0.40 \mathrm{mS} / \mathrm{cm}$. Concerning the survey carried out in May 2010 (CHIODINI et alii, 2012), the surface water temperature in April 2019 was considerably lower $\left(13.2{ }^{\circ} \mathrm{C}\right.$ vs $\left.17.2{ }^{\circ} \mathrm{C}\right)$, whereas, oppositely, Layer II water in May 2010 was colder (minimum $8.7^{\circ} \mathrm{C}$ ) compared to April 2019 (minimum 9.1 ${ }^{\circ} \mathrm{C}$ ). In the long-term, the Layer II water temperature seems to be higher in recent years $\left(7^{\circ} \mathrm{C}-8.5^{\circ} \mathrm{C}\right.$ reported by CIONI et alii, 2003, for November 1995).

The epilimnion (top $20 \mathrm{~m}$ ) and the thermocline between approximately 5 and $15 \mathrm{~m}$ depth are represented in Fig. 3. The point of overturning of this trend is at approximately $9 \mathrm{~m}$, as observed by CHIODINI et alii (2012) for May 2010, although less abrupt than that recorded in the April 2019 survey. The better defined thermal stratification in May 2010, with respect to April 2019 (a month earlier into spring), could be due to the atmospheric effect of the lake heading towards more stable stratification in summer.

\section{SOLUTES AND DISSOLVED GASES}

The chemical composition of main solutes and dissolved gas species collected along the vertical profile of Lago Albano is reported in Tables 1 and 2, respectively.

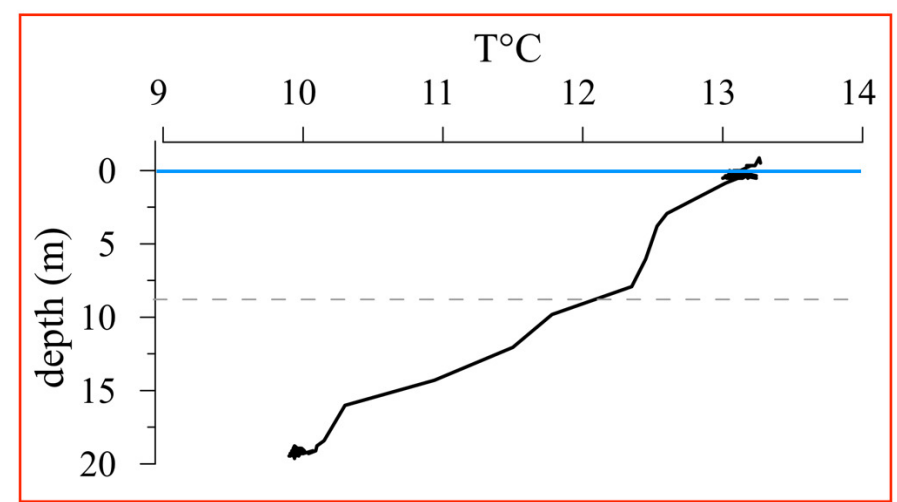

Fig. 3 - Temperature trend in the upper $20 \mathrm{~m}$ of Lago Albano (epilimnion). The blue line indicates the lake surface; the red square is the zoomed area as shown in Fig. 2. The dotted grey line indicates the 9 me depth thermocline as detected by CHIODINI et alii (2012).

The vertical distribution of major anions and cations in the Lago Albano water column is relatively stable from bottom to top. Figure 4 compares the April 2019 solute concentrations with those of May 2010 (CHIODINI et alii, 2012). Sulfate and $\mathrm{Cl}^{-}$slightly increased with respect to those measured in May 2010; the rather peculiar major cation contents clearly reflect the incongruent dissolution process of $\mathrm{K}_{2} \mathrm{O}$-CaO-rich, Mg-poor K-foidites, phonotephrites and tephrites of the wall rock of the Colli Albani volcano (Trigila et alii, 1995). Nevertheless, for May 2010, the $\mathrm{Na}^{+}$ and $\mathrm{K}^{+}$concentrations were lower, whereas $\mathrm{Mg}^{2+}$ and $\mathrm{Ca}^{2+}$ concentrations remained stable. For the first time since the 
TABLE 1

Temperature, $\mathrm{pH}$ and chemical composition of solute species in Lago Albano lake water along the vertical profile (in $\mathrm{mg} / \mathrm{L})$. TDS $=$ Total Dissolved Solids. Nm = not measured.

\begin{tabular}{|c|c|c|c|c|c|c|c|c|c|c|}
\hline Depth & $\mathbf{T}\left({ }^{\circ} \mathbf{C}\right)$ & $\mathbf{p H}$ & $\mathbf{C a}^{2+}$ & $\mathbf{M g}^{2+}$ & $\mathbf{N a}^{+}$ & $\mathbf{K}^{+}$ & Alkalinity & $\mathbf{C l}^{-}$ & $\mathbf{S O}_{\mathbf{4}}{ }^{2-}$ & $\mathbf{T D S}^{-}$ \\
\hline 0 & 13,05 & 8.47 & 21,1 & 15,8 & 27 & 42,7 & 269 & 19,7 & 8,1 & 403,4 \\
\hline-10 & 11,78 & 8.52 & 24,6 & 17 & 31,1 & 43,6 & 261 & 20,1 & 8 & 405,4 \\
\hline-20 & 9,91 & 8.31 & 24 & 16,9 & 30,5 & 43,8 & 262 & 20,2 & 8,1 & 405,5 \\
\hline-30 & 9,56 & 7.98 & 21,5 & 16,3 & 26,7 & 44 & 271 & 20,6 & 8,1 & 408,2 \\
\hline-40 & 9,46 & 8.32 & 24,3 & 16,8 & 30,5 & 44,3 & 265 & 19,8 & 8 & 408,7 \\
\hline-50 & 9,37 & 8.2 & 24,3 & 16,9 & 30,6 & 44,2 & 266 & 19,6 & 8 & 409,6 \\
\hline-60 & 9,35 & 8.26 & 21,4 & 16 & 25,6 & 43,1 & 265 & 19,7 & 8 & 398,8 \\
\hline-70 & 9,32 & 7.93 & 24,1 & 16,8 & 30,7 & 44 & 266 & 19,8 & 8,1 & 409,5 \\
\hline-80 & 9,28 & 7.89 & 24 & 16,7 & 30,5 & 43,3 & 264 & 19,7 & 8 & 406,2 \\
\hline-90 & 9,21 & 7.89 & 22,8 & 16,4 & 28,3 & 43,6 & 266 & 19,8 & 8,1 & 405 \\
\hline-100 & 9,22 & 7.86 & 24,5 & 16,8 & 30,6 & 43,3 & 273 & 19,6 & 8 & 415,8 \\
\hline-110 & 9,19 & 7.66 & 24,4 & 16,8 & 29,9 & 43 & 271 & 19,6 & 7,9 & 412,6 \\
\hline-120 & 9,18 & 7.62 & 24,8 & 16,6 & 30,2 & 42,7 & 279 & 19,7 & 7,9 & 420,9 \\
\hline-130 & 9,18 & 7.68 & 26,3 & 16,8 & 28,5 & 43,6 & 284 & 19,5 & 7,5 & 426,2 \\
\hline-140 & 9,15 & 7.83 & 25,6 & 16,8 & 29,5 & 43,5 & 281 & 19,6 & 7,5 & 423,5 \\
\hline-150 & Nm & 7.7 & 26,8 & 16,7 & 30,1 & 42,8 & 286 & 19,4 & 7,1 & 428,9 \\
\hline bottom & Nm & 7.62 & 25,8 & 16,7 & 26 & 41,6 & 283 & 19,4 & 7,2 & 419,7 \\
\hline
\end{tabular}

TABLE 2

Chemical composition of dissolved gas species and their isotopic compositions in Lago Albano lake water along the vertical profile. $\mathrm{Nm}=$ not measured, $\mathrm{bdl}=$ below detection limit.

\begin{tabular}{|c|c|c|c|c|c|c|c|c|c|c|c|c|c|c|c|}
\hline Depth & $\mathrm{CO}_{2}$ & $\mathrm{CO}_{2}$ & $\mathrm{CO}_{2}$ & $\mathrm{CO}_{2}$ & $\delta^{13} \mathrm{C}_{\mathrm{DIC}}$ & $\delta^{13} \mathrm{C}_{\mathrm{CO} 2}$ & $\mathrm{~N}_{2}$ & $\mathrm{Ar}$ & $\mathrm{CH}_{4}$ & $\delta^{13} \mathrm{C}_{\mathrm{CH} 4}$ & $\mathrm{H}_{2}$ & $\mathrm{He}$ & ${ }^{3} \mathrm{He} /{ }^{4} \mathrm{He}$ & ${ }^{4} \mathrm{He} /{ }^{20} \mathrm{Ne}$ & Total gas \\
\hline $\mathbf{m}$ & $\mathrm{mmol} / \mathrm{kg}$ & $\mu a t m$ & $\begin{array}{c}\mu \mathrm{atm} \\
\text { (probe) } \\
16 \text { April } \\
2019\end{array}$ & $\begin{array}{c}\text { uatm } \\
\text { (probe) } \\
28 \text { June } \\
2019\end{array}$ & $\begin{array}{l}\% o \text { vs. } \\
\text { VPDB }\end{array}$ & $\begin{array}{l}\% o \text { vs. } \\
\text { VPDB }\end{array}$ & $\mathrm{mmol} / \mathrm{kg}$ & $\mathrm{mmol} / \mathrm{kg}$ & $\begin{array}{c}\mathrm{mmol} / \mathrm{k} \\
\mathrm{g}\end{array}$ & $\begin{array}{l}\% o \text { vs. } \\
\text { VPDB }\end{array}$ & $\mathrm{mmol} / \mathrm{kg}$ & $\mathrm{mmol} / \mathrm{kg}$ & $\left(\mathrm{R}_{\mathrm{C}} / \mathrm{R}_{\mathrm{A}}\right)$ & & $\mathrm{mmol} / \mathrm{kg}$ \\
\hline $\mathbf{0}$ & $\mathrm{Nm}$ & $\mathrm{Nm}$ & $\mathrm{Nm}$ & $\mathrm{Nm}$ & 3.17 & $\mathrm{Nm}$ & $\mathrm{Nm}$ & $\mathrm{Nm}$ & $\mathrm{Nm}$ & $\mathrm{Nm}$ & bdl & $\mathrm{Nm}$ & $\mathrm{Nm}$ & $\mathrm{Nm}$ & $\mathrm{Nm}$ \\
\hline-10 & 0.02 & 424 & 200 & 100 & 2.86 & -8.11 & 0.68 & 0.016 & 0.000 & -48.4 & bdl & $8.60 \mathrm{E}-06$ & $\mathrm{Nm}$ & $\mathrm{Nm}$ & 0.855 \\
\hline-20 & 0.04 & 750 & 1200 & 1800 & 2.23 & -7.7 & 0.66 & 0.015 & 0.000 & -49.1 & bdl & $8.50 \mathrm{E}-06$ & $\mathrm{Nm}$ & $\mathrm{Nm}$ & 0.886 \\
\hline-30 & 0.10 & 1827 & $\mathrm{Nm}$ & $\mathrm{Nm}$ & 3.12 & -6.95 & 0.69 & 0.017 & 0.000 & -46.4 & bdl & $8.15 \mathrm{E}-06$ & $\mathrm{Nm}$ & $\mathrm{Nm}$ & 1.022 \\
\hline-40 & 0.11 & 2115 & 2000 & 2400 & 3.25 & $\mathrm{Nm}$ & 0.65 & 0.015 & 0.000 & $\mathrm{Nm}$ & bdl & $6.90 \mathrm{E}-06$ & $\mathrm{Nm}$ & $\mathrm{Nm}$ & 1.038 \\
\hline-50 & 0.13 & 2440 & $\mathrm{Nm}$ & $\mathrm{Nm}$ & 3.53 & -6.87 & 0.68 & 0.016 & 0.000 & -49.9 & bdl & $7.80 \mathrm{E}-06$ & $\mathrm{Nm}$ & $\mathrm{Nm}$ & 0.955 \\
\hline-60 & 0.19 & 3566 & 3100 & 3200 & 3.18 & -5.95 & 0.69 & 0.017 & 0.000 & -47.9 & bdl & $8.60 \mathrm{E}-06$ & $\mathrm{Nm}$ & $\mathrm{Nm}$ & 0.973 \\
\hline-70 & 0.21 & 3942 & $\mathrm{Nm}$ & $\mathrm{Nm}$ & 1.33 & -6.7 & 0.71 & 0.018 & 0.001 & -47.2 & bdl & $1.10 \mathrm{E}-05$ & $\mathrm{Nm}$ & $\mathrm{Nm}$ & 1.056 \\
\hline-80 & 0.25 & 4692 & 4500 & 4600 & 2.55 & $\mathrm{Nm}$ & 0.69 & 0.016 & 0.002 & $\mathrm{Nm}$ & bdl & 1.29E-05 & $\mathrm{Nm}$ & $\mathrm{Nm}$ & 1.273 \\
\hline-90 & 0.31 & 5819 & $\mathrm{Nm}$ & $\mathrm{Nm}$ & 3.34 & $\mathrm{Nm}$ & 0.72 & 0.017 & 0.004 & -50.6 & bdl & $1.04 \mathrm{E}-05$ & $\mathrm{Nm}$ & $\mathrm{Nm}$ & 1.526 \\
\hline-100 & 0.39 & 7320 & 7500 & 6800 & 2.24 & $\mathrm{Nm}$ & 0.69 & 0.017 & 0.006 & $\mathrm{Nm}$ & bdl & $1.14 \mathrm{E}-05$ & $\mathrm{Nm}$ & $\mathrm{Nm}$ & 1.641 \\
\hline-110 & 0.44 & 8259 & $\mathrm{Nm}$ & $\mathrm{Nm}$ & 3.09 & -5.97 & 0.71 & 0.018 & 0.092 & -46.5 & $2.10 \mathrm{E}-06$ & $1.29 \mathrm{E}-05$ & $\mathrm{Nm}$ & $\mathrm{Nm}$ & 1.685 \\
\hline-120 & 0.51 & 9572 & 8900 & 7900 & 2.37 & $\mathrm{Nm}$ & 0.70 & 0.017 & 0.130 & $\mathrm{Nm}$ & $6.60 \mathrm{E}-06$ & 1.10E-05 & $\mathrm{Nm}$ & $\mathrm{Nm}$ & 1.756 \\
\hline-130 & 0.59 & 11074 & $\mathrm{Nm}$ & $\mathrm{Nm}$ & 1.83 & $\mathrm{Nm}$ & 0.72 & 0.016 & 0.190 & -55.4 & $1.90 \mathrm{E}-05$ & $6.74 \mathrm{E}-06$ & $\mathrm{Nm}$ & $\mathrm{Nm}$ & 1.909 \\
\hline-140 & 0.63 & 11825 & 9400 & 8700 & 2.03 & -5.25 & 0.69 & 0.017 & 0.220 & $\mathrm{Nm}$ & $1.80 \mathrm{E}-04$ & $9.08 \mathrm{E}-06$ & 1.090 & 0.340 & 1.947 \\
\hline-150 & 0.69 & 12951 & $\mathrm{Nm}$ & $\mathrm{Nm}$ & 1.35 & -4.51 & 0.68 & 0.015 & 0.290 & $\mathrm{Nm}$ & $6.10 \mathrm{E}-04$ & $1.02 \mathrm{E}-05$ & 0.930 & 0.380 & 2.020 \\
\hline bottom & 0.71 & 13326 & $\mathrm{Nm}$ & $\mathrm{Nm}$ & 2.01 & $\mathrm{Nm}$ & 0.71 & 0.015 & 0.310 & $\mathrm{Nm}$ & $9.60 \mathrm{E}-04$ & $8.62 \mathrm{E}-06$ & 0.940 & 0.340 & 2.129 \\
\hline
\end{tabular}




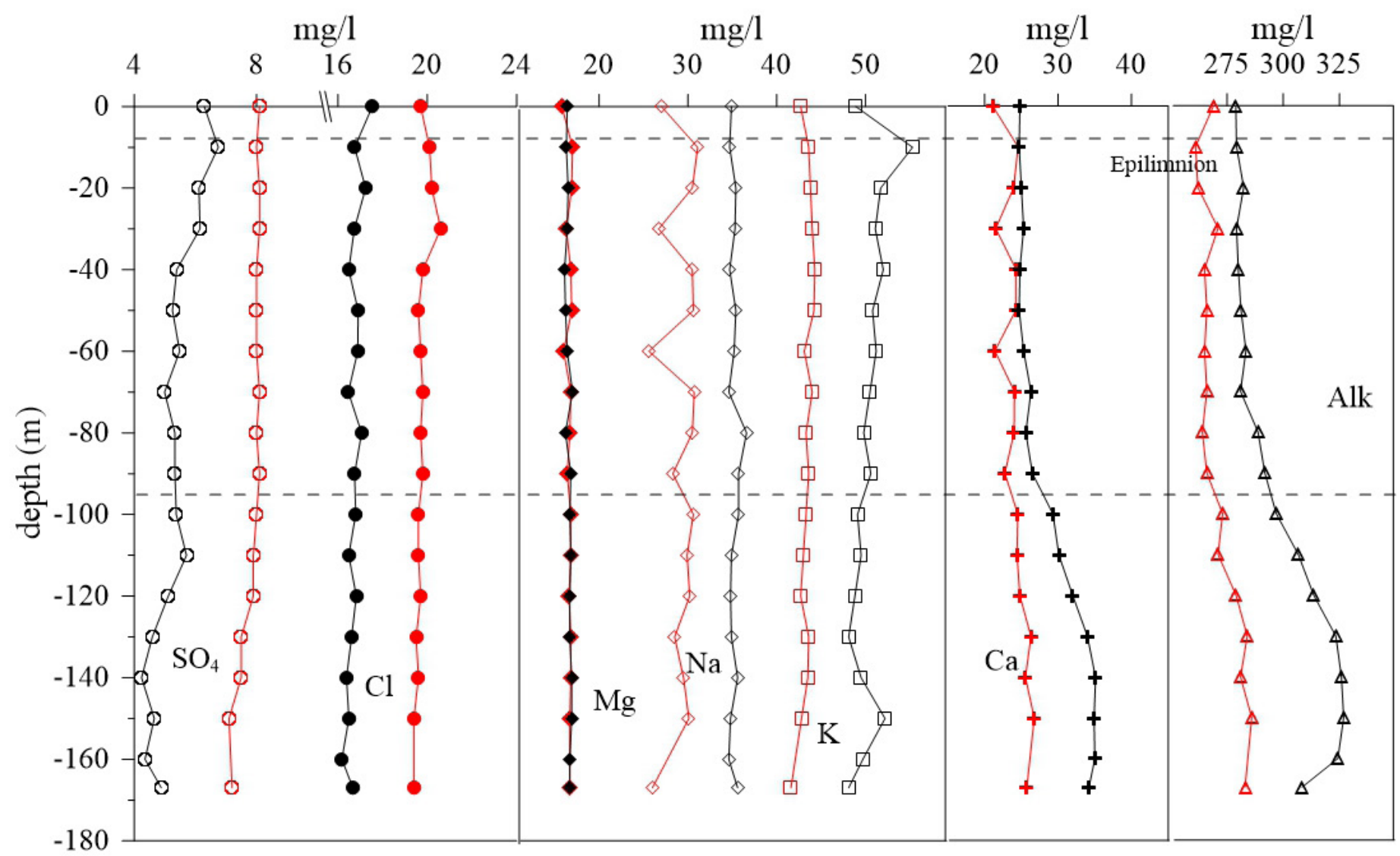

Fig. 4 - Variations in concentrations of the main solutes and alkalinity for May 2010 (black symbols) and April 2019 (red symbols) along the vertical profile of Lago Albano. The dotted horizontal lines delimit the various layers, based on observed physicochemical parameters.

first survey in March 1989, alkalinity remained practically stable along the vertical profile.

Considering the decreasing trend in dissolved C-bearing gases observed after the April 1989-March 1990 seismic swarm beneath the western sector of Colli Albani volcano (АмAто et alii, 1994), the no-occurrence of renewed seismic activity in the area posteriorly, the degassing model proposed by CHIODINI et alii (2012) and the revised hazard assessment by Rouwet et alii (2019), a drastic drop in dissolved C content in April 2019, after the gap in data gathering of almost nine years, would have been expected. Figure 5 indeed shows that dissolved $\mathrm{CO}_{2}$ concentrations dropped by a factor $\sim 2$, whilst that of dissolved $\mathrm{CH}_{4}$ decreased by a factor $\sim 1.5$ in the hypolimnion (Table 2 ). Methane was detected at $-100 \mathrm{~m}$ in April 2019, whereas it was registered at $-90 \mathrm{~m}$ in May 2010. In April 2019, the typical atmospheric gas species, $\mathrm{N}_{2}$ and Ar, showed similar trends and absolute concentrations than those recorded in May 2010. Hydrogen was detected at $-110 \mathrm{~m}$, in the fully anoxic environment. Helium concentrations (not reported for May 2010) showed slightly more variability towards the bottom of the lake in April 2019.

The helium isotope ratios $\left({ }^{3} \mathrm{He} /{ }^{4} \mathrm{He}\right.$ in $\left.\mathrm{Ra}\right)$ from -140 $\mathrm{m}$ to the lake bottom were ranging from $0.92 \mathrm{R}_{\mathrm{A}}$ to 1.09 $R_{A}$ (Table 2). Although apparently low, they are within the interval determined for gas emissions in the Colli Albani area (0.94-1.90 $\mathrm{R}_{\mathrm{A}}$; CARAPEZZA \& TARCHINI, 2007), and are slightly lower than the ${ }^{3} \mathrm{He} /{ }^{4} \mathrm{He}$ ratios measured in olivinephenocryst fluid inclusions (1.17-1.70 $\mathrm{R}_{\mathrm{A}}$; MARTELLI et alii, 2004), and the last ${ }^{3} \mathrm{He} /{ }^{4} \mathrm{He}$ ratio reported for dissolved gases at Lago Albano (1.30 $\mathrm{R}_{\mathrm{A}}$; CARAPEzza et alii, 2008). A ${ }^{3} \mathrm{He} /{ }^{4} \mathrm{He}$ ratio slightly higher than $1 \mathrm{R}_{\mathrm{A}}$ confirms the small contribution of a deep magmatic component to the hydrothermal system beneath Lago Albano.

The higher dissolved $\mathrm{CO}_{2}$ contents towards the hypolimnion are reflected by a lower $\mathrm{pH}$ and higher alkalinity towards the bottom (Fig. 6). Plotting the temporal evolution of $\mathrm{pH}$ and alkalinity (where alkalinity is a proxy of $\mathrm{HCO}_{3}{ }^{-}$concentration) for the past 30-years (1989-2019) (Fig. 6, data for pre-2010 and 2010 are from supplementary material in CHIODINI et alii, 2012), the loss of $\mathrm{CO}_{2}$ by annual degassing is manifested as a $\mathrm{pH}$ increase; apparently, this trend has remained stable for the past nine years. The April $2019 \mathrm{pH}$ and alkalinity distributions appear to be relatively homogeneous along the vertical profile concerning previous surveys. This observation suggests a decrease in lake stratification that directly affects dissolved gas composition, and coincident with the more gradual $\mathrm{CO}_{2}$ distribution along the vertical profile, compared to the May 2010 trend (Fig. 6).

Carbonate precipitation should be investigated as a potential $\mathrm{CO}_{2}$-sink, especially if the $\mathrm{pH}$ of Lago Albano water will be increasing in the future. In fact, calcite and dolomite are saturated in the top $100 \mathrm{~m}$ of Lago Albano (SI 0.08 at $-100 \mathrm{~m}$ to 0.66 at $0 \mathrm{~m}, \mathrm{SI}_{\text {dolomite }}$ from 0.11 at $-100 \mathrm{~m}$ to 1.37 at $0 \mathrm{~m}$ ). Further details are needed to conceptualize and quantify the effect of carbonate precipitation on the total $\mathrm{C}$ budget of the lake, in time and space. Instead, the sulfate species anhydrite and gypsum are highly undersaturated along the entire lake depth profile. 


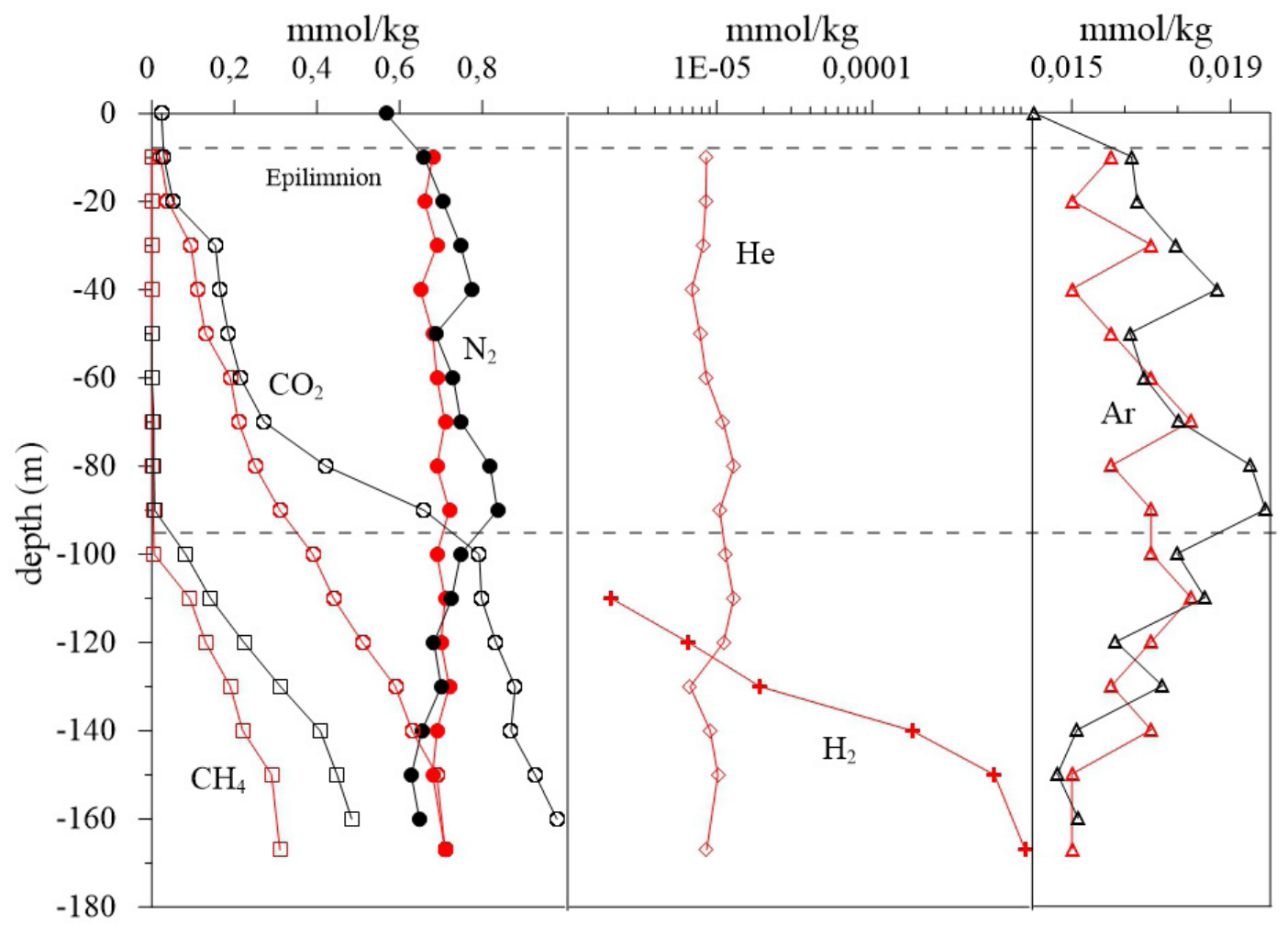

Fig. 5 - Variations in concentrations of dissolved gas species along the vertical profile of Lago Albano for May 2010 (black symbols) and April 2019 (red symbols). The dotted horizontal lines delimit the various layers, based on observed physicochemical parameters.

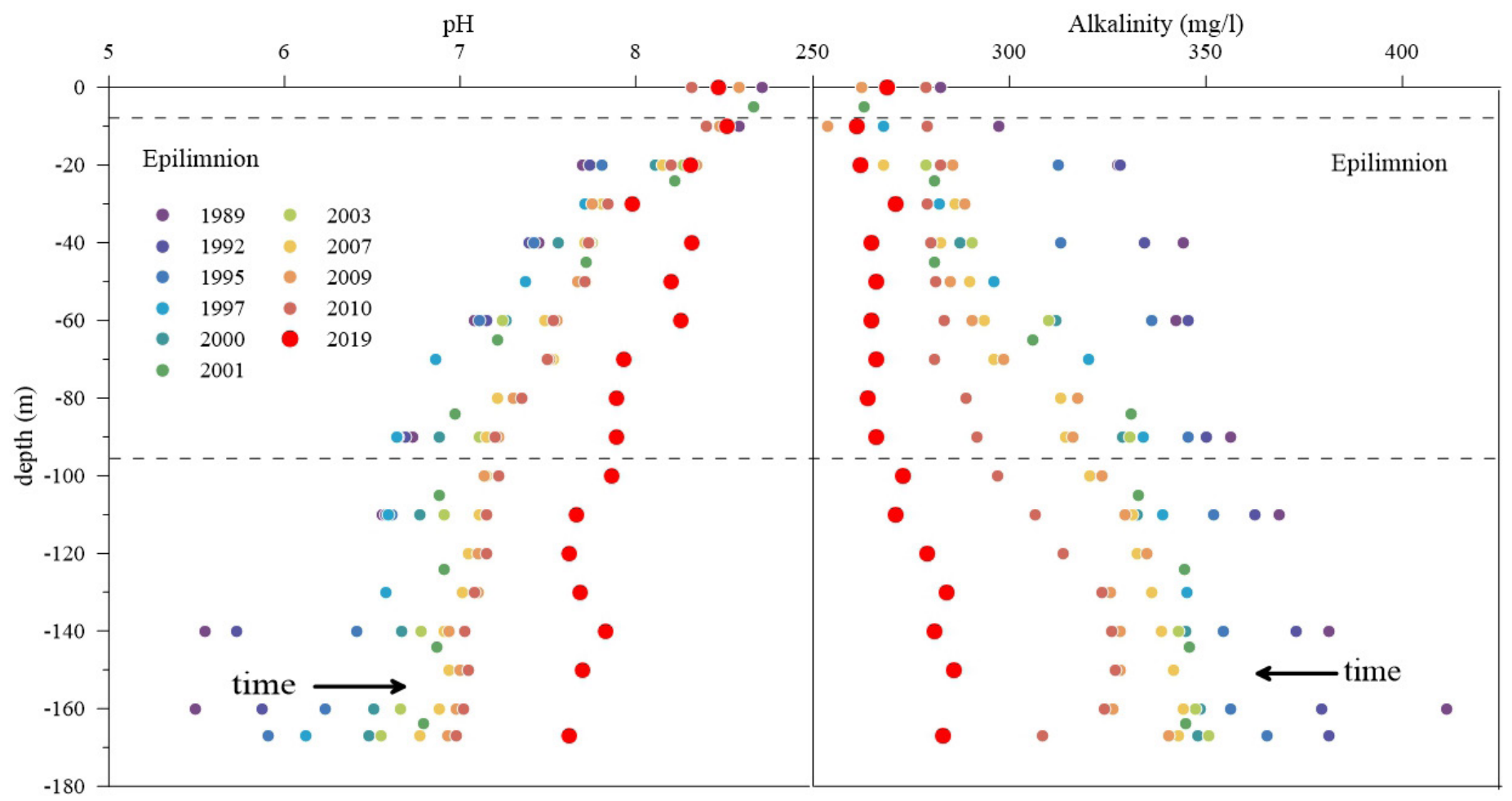

Fig. 6 - Measured $\mathrm{pH}$ and alkalinity (as $\mathrm{mg} / \mathrm{L}_{\text {of }} \mathrm{HCO}_{3}{ }^{-}$) along the vertical profile of Lago Albano for the three decades of observations (19892019). The time-related decrease of alkalinity and $\mathrm{pH}$ increase arguably result from $\mathrm{CO}_{2}$ removal by degassing.

\section{ISOTOPES}

Table 2 and Fig. 7 report on how the $\delta^{13} \mathrm{C}_{\text {pIC }}$ values decrease (as it did in May 2010; CHIODINI et alii, 2012), whereas the $\delta^{13} \mathrm{C}_{\mathrm{CO} 2}$ increase from top to bottom. This observation might suggest the release of isotopically light $\mathrm{CO}_{2}$ by diffusion, leaving the remnant DIC in the lake water isotopically heavier (CHIODINI et alii, 2012). As also stated by the ${ }^{3} \mathrm{He} /{ }^{4} \mathrm{He}$ isotopic ratios, part of the $\mathrm{CO}_{2}$ clearly has 


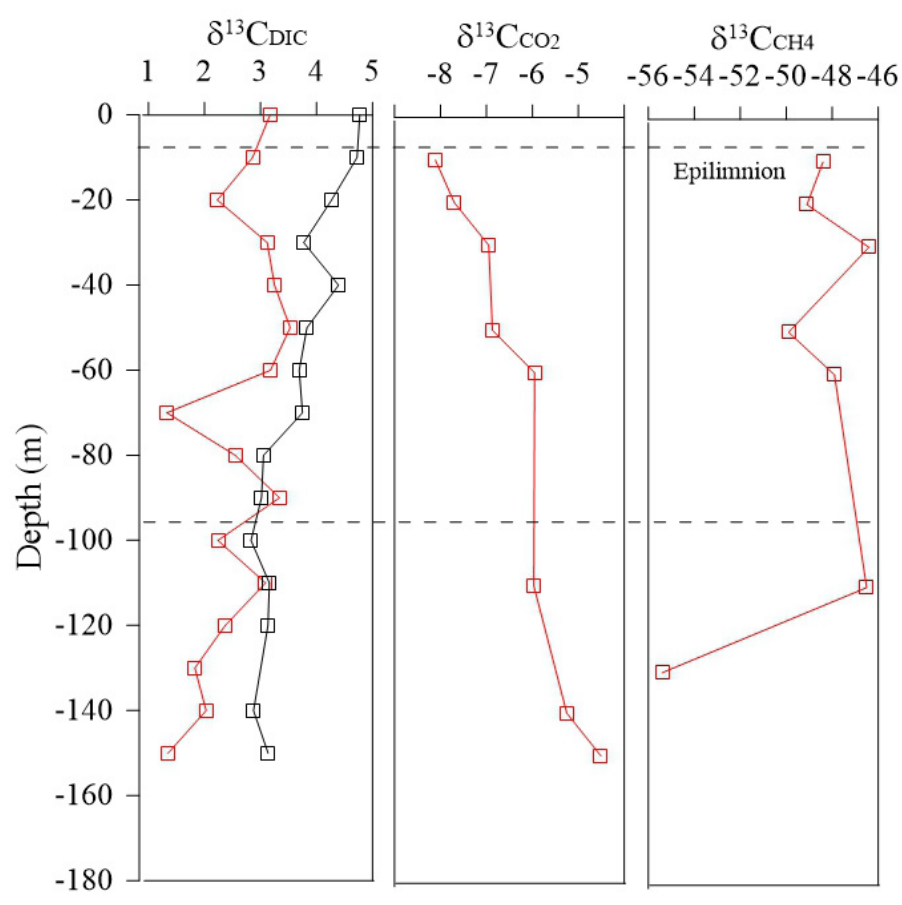

Fig. 7 - Variations in isotopic compositions $\delta^{13} \mathrm{C}_{\mathrm{TDIC}} \delta^{13} \mathrm{C}_{\mathrm{CO} 2} \delta^{13} \mathrm{C}_{\mathrm{CH} 4}$ for dissolved C-gases along the vertical profile of Lago Albano. Black symbols are the $\delta^{13} \mathrm{C}_{\mathrm{TDC}}$ for the May 2010 gases (CABASSI et alii, 2013). Red symbols refer to the April 2019 data.

a magmatic origin, on its turn isotopically enriched by interaction with the carbonate basement rocks (CHIODINI et alii, 2012; and references therein). The highly negative and stable $\delta^{13} \mathrm{C}_{\mathrm{CH} 4}$ values in the top-110 $\mathrm{m}$ of Lago Albano, indicative of methane production within the lake mainly related to microbial activity (CABASSI et alii, 2013), spike near the bottom to more negative values due to the higher $\mathrm{CH}_{4}$ contents below $100 \mathrm{~m}$ depth and a possible interaction with organic-rich bottom sediments (Fig. 5 and 7).

\section{INTER-COMPARISON $\mathrm{CO}_{2}$ PROBE VERSUS DIRECT SAMPLING}

Table 2 presents the $\mathrm{CO}_{2}$ concentrations along the vertical profile based on the direct sampling method also expressed as $\mu \mathrm{atm}$ to make the results comparable with the April 2019 in-lake $\mathrm{CO}_{2}$ probe measurements. Figure 8 shows that the $\mathrm{CO}_{2}$ concentrations measured by the infra-red ProOceanus Mini-CO, probe (blue dots in Fig. 8) well correlate with the concentrations determined on the collected samples and posteriorly analyzed for $\mathrm{CO}_{2}$. The deviation from the 1:1 correlation in Fig. 8 for the deepest measurements is probably due to the still too short measurement time to reach asymptotic $\mathrm{CO}_{2}$ conditions, arguably resulting in underestimates for dissolved $\mathrm{CO}_{2}$ concentrations. Nevertheless, given the strong correlation, probe measurements can become an efficient and less time-consuming operation, promising for future $\mathrm{CO}_{2}$ monitoring at Lago Albano, or elsewhere. Moreover, the June 2019 probe measurements did not differ significantly concerning the April 2019 (not shown as a figure) to have an impact on the $\mathrm{CO}_{2}$ budget of the lake on such a short-term observation (see section 5). However, the probe sensibility is high enough to detect minor changes in dissolved $\mathrm{CO}_{2}$ content during the same day at various depths or sites, when left for approximately 20 minutes at fixed measurement depths.

\section{A REVISED DEGASSING MODEL}

Here we applied a $\mathrm{CO}_{2}$ budget analysis for the different lake strata to update the degassing model of Lago Albano for the past three decades. This approach is based on the assumption that the total $\mathrm{CO}_{2}$ content, expressed as DIC (dissolved inorganic carbon), and measured every $10 \mathrm{~m}$ along the deepest vertical profile of the lake, is horizontally homogeneously distributed throughout the entire lake. The carbonate alkalinity is approximated by the $\mathrm{HCO}_{3}$ concentration, whereas DIC is considered here as the sum of $\mathrm{HCO}_{3}^{-}$and dissolved $\mathrm{CO}_{2}$ concentrations (both in $\mathrm{mmol} / \mathrm{kg}$ ), controlled by the measured $\mathrm{pH}$. The total DIC present in each $10 \mathrm{~m}$-thick lake stratum (DICT in tons) is calculated by multiplying the DIC concentrations by the volume of each stratum, which is estimated considering (1) the linear trend in lake level drop since 1989 (MAzza et alii, 2015; a total lake level drop of approximately $6.1 \mathrm{~m}$ between 1989 and 2019, due to excessive well pumping), and (2) the November 2005 bathymetric survey by ANZIDEI et alii (2008) as the reference volume.

The DICT largely depends on the volume of each stratum (Fig. 9a, b), and hence the lake basin morphology (Fig. 9c). The temporal evolution of the carbon concentrations and the total contents distribution (DIC and DICT) in the various lake strata between 1989 and 2019 becomes evident (Fig. 9a,b). The initially post-seismicity (19891992) DIC abundance in the deep layers dropped through degassing and evolved towards a steady-state regime since 1995-1997. During the past two decades, trend lines point towards lower DIC and DICT contents and approach each other in Fig. 9a and b, respectively, suggesting a more gradual release of $\mathrm{CO}_{2}$. The ramping trend lines for the

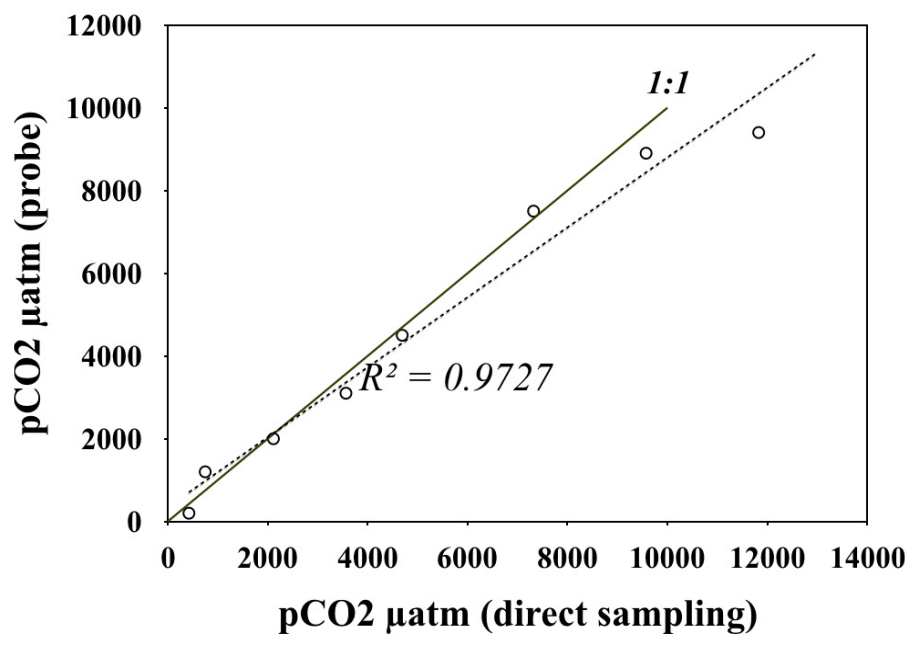

Fig. 8 - Inter-comparison between the $\mathrm{CO}_{2}$ concentrations measured by the infra-red ProOceanus Mini- $\mathrm{CO}_{2}$ probe and the $\mathrm{CO}_{2}$ concentrations upon direct sampling and analyses. The dotted line shows the correlation and its corresponding $\mathrm{R}^{2}$, whereas the black line shows the 1:1 proportion between measured and sampled $\mathrm{CO}_{2}$ concentrations. 


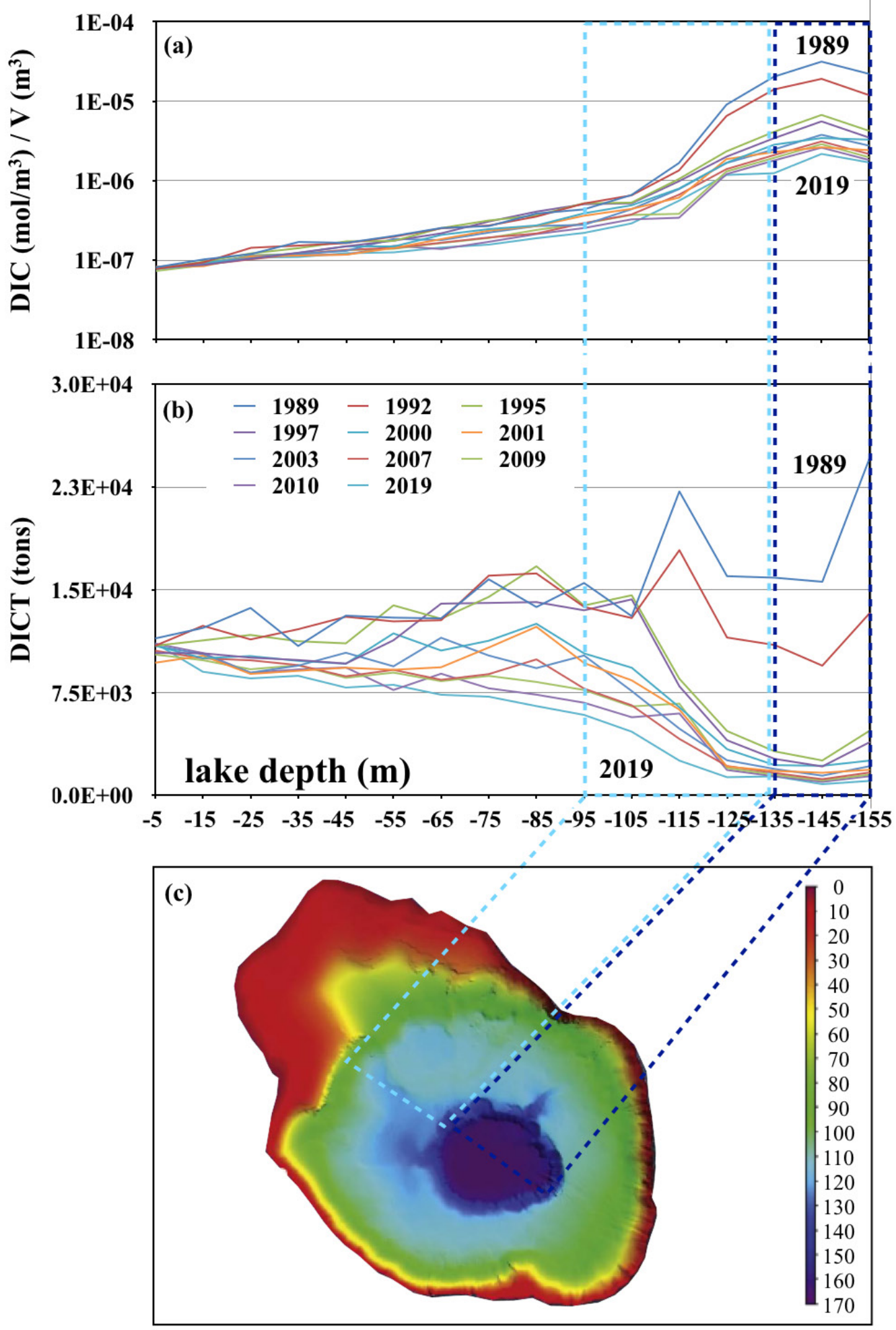

Fig. 9 - DIC contents per 10 $\mathrm{m}$-thick strata in relation to the volume of the corresponding lake stratum. (a) The DIC/V plot shows higher values for the deep strata, especially for 1989-1992, the years shortly after the 1989-1990 seismic swarm at Colli Albani (Амато et alii, 1994). (b) The amount of DICT (in tons) for each 10 m-thick strata, considering the dropping lake level and decreasing volume. (c) The bathymetric map (modified from ANZIDEI et alii, 2008) of Lago Albano showing visualizing the relationship between the DICT distribution and the lake morphology of the lake basin.

depth interval between -125 and $-95 \mathrm{~m}$ reflect the widening of the lake basin at these depths, although this widening of the lake basin could also actively affect the degassing dynamics of Lago Albano due to a $\mathrm{CO}_{2}$ concentration gradient between the pit and wider parts of the lake basin. It is to be pointed out that degassing at Lago Albano is paired with the yearly winter rollover of the epilimnion
(CARAPEZza et alii, 2008; Chiodini et alii, 2012) and that the calculations are here based on data sets with a frequency generally higher than one year (1 to 9 years). The loss of DIC from the lake, as shown here, is hence a time-averaged and longer-term process, unable to better describe the seasonal and single degassing events. As already suggested by the alkalinity and dissolved $\mathrm{CO}_{2}$ content in Table 1 and Figs. 
4 and 5, DIC and DICT have decreased with time through degassing, and it resulted in being better distributed along the vertical profile (Fig. 9a, b).

With the reasonable assumption that the $\mathrm{CO}_{2}$ degasses from the surface of Lago Albano during the two months from mid-December to mid-February (CHIODINI et alii, 2012; Rouwet et alii, 2019), the $\mathrm{CO}_{2}$ (DIC) flux decreased from 38 tons $/ \mathrm{km}^{2} \mathrm{~d}$ in 1995 to $1.9-3.9$ tons $/ \mathrm{km}^{2} \mathrm{~d}$ for the period 2009-2019. These fluxes are of the same order of magnitude as those directly measured (using the floating accumulation chamber method; CHIODINI et alii, 1998; MAzot et alii, 2011) and reported by PÉrez et alii (2011) at many volcanic lakes worldwide. These authors did not consider - though should have, the fact that $\mathrm{CO}_{2}$ degassing from alkaline and neutral-pH lakes can be highly seasondependent in temperate climate regions. Direct $\mathrm{CO}_{2}$ flux measurements from the surface of Lago Albano using the floating accumulation chamber should be executed in the future, during both winter and summer, to probably highlight this seasonal degassing trend.

With the scope to detail on the DIC distribution among the various lake strata, the loss of DICT from each stratum toward the lake surface can be expressed in terms of a flux (tons/d). Fluxes are calculated, as follows:

$\mathrm{Q}_{\text {DICT }}($ tons $/ \mathrm{d})=\left[\mathrm{DICT}_{\text {stratum x at t0 }}-\mathrm{DICT}_{\text {stratum x at t1 }}\right] /\left(\mathrm{t}_{1}-\mathrm{t}_{0}\right)$

where DICT stratum $_{\text {x }}$ is the amount of DICT (in tons) at the time $t_{0}$ and $t_{1}$ (i.e. the sampling period immediately available after $t_{0}$ ) in the $10 \mathrm{~m}$-thick stratum at a depth $\mathrm{x}, \mathrm{t}_{1}-\mathrm{t}_{0}$ is the time difference between two periods of observation (in days) and $\mathrm{Q}_{\text {DICT }}$ is the DICT flux out of each stratum toward the lake surface. We then calculated averages and standard deviations of $Q_{\text {DICT }}$ values for three periods: (i) post-seismicity (1989-1995; Fig. 10a), (ii) the last two decades (1997-2019; Fig. 10b) and (iii) the entire three decades of observation (1989-2019; Fig. 10c).

The DICT fluxes from the bottom strata are the highest for the post-seismicity period (1989-1995) (Fig. 10a); the high standard deviations suggest a high natural variability in DICT fluxes from depth, in agreement with an unstable degassing regime. Average fluxes from deep layers are 6-8.5 t/d, though smoothed over a longer period (2-3 years) and can be even higher at certain moments. Seismically induced $\mathrm{CO}_{2}$ recharge can thus be followed by an unstable and more vigorous degassing regime for the years to come. Although the pre-1989 DIC content was far from saturation conditions, unstable degassing could result in hazardous gas release in the future, as was arguably the case after the three seismic crises in 1829 , 1873 and 1883 (Rouwet et alii, 2019).

The DICT loss from the bottom layers has drastically been dropping since 1997, but it constantly increased from $-125 \mathrm{~m}$ to peak at $-95 \mathrm{~m}$ depth, and between -85 and $-75 \mathrm{~m}$ depth (Fig. 10b), the $-95 \mathrm{~m}$ depth coinciding with the thermocline and chemocline between Layer I and II (CHIOdini et alii, 2012). This chemocline is based on the measured concentration variations in solute and dissolved gas species and is hence not an effect of the changes in lake basin morphology at these depth ranges. With standard deviations keeping the pace of DICT fluxes for this depth range, a stable degassing process since 1997 is suggested. The larger water volume suddenly available when rising out of the deep pit basin appears to instigate
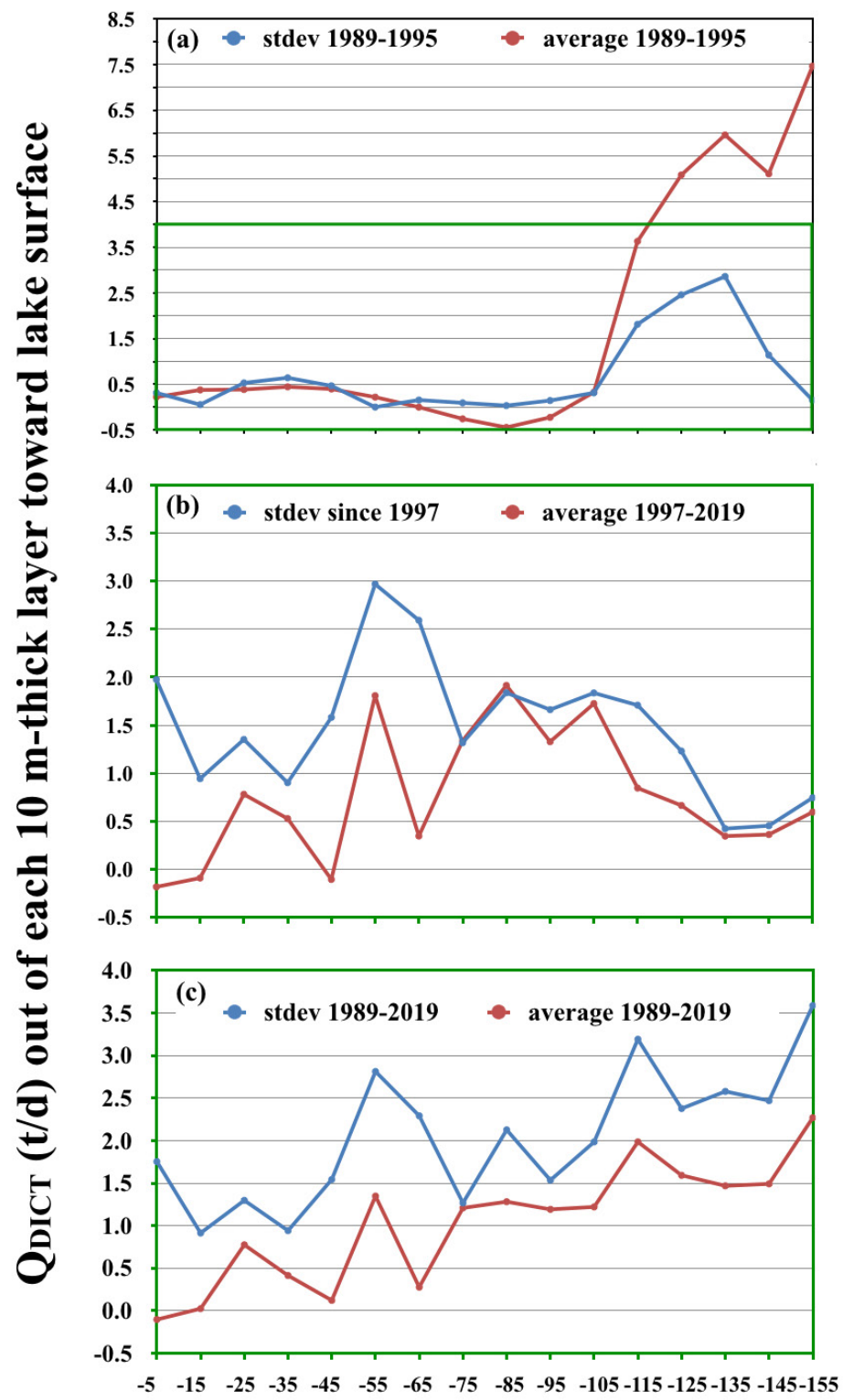

lake depth (m)

Fig. 10 - Variations in average fluxes of DICT $\left(\mathrm{Q}_{\mathrm{DICT}}\right)$ and standard deviations of fluxes out of each 10 m-thick stratum to the stratum above for various time intervals (a) 1989-1995 (average fluxes and their standard deviations for August 1992 and April 1995), the years shortly after the seismic swarm at Colli Albani (Амато et alii, 1994). The high fluxes from the bottom strata illustrate the initially high DICT release from bottom waters by diffuse degassing, (b) since 1997 (average fluxes and their standard deviations for December 1997, July 2000, July 2001, March 2003, May 2007, September 2009, May 2010 and April 2019) showing low fluxes from the bottom strata and higher fluxes towards the shallower strata. Note the ramping up of $\mathrm{Q}_{\mathrm{DTc}}$ at depths between -125 and $-95 \mathrm{~m}$ and -75 and $-55 \mathrm{~m}$, (c) average DICT fluxes and their standard deviations for the entire period of observation (from August 1992 to April 2019), i.e. combining (a) and (b). The volumes of the lake strata are estimated considering the lake level drop of approximately $6.1 \mathrm{~m}$ between 1989 and 2019 (from MAzZA et alii, 2015) given the 2005 lake bathymetry by ANZIDEI et alii (2008).

increased DICT release and mitigate the release into the atmosphere.

Between -95 and -25 $\mathrm{m}$ depth, after peaking at -55 $\mathrm{m}$ depth, the inter-strata DICT fluxes steadily decreased, being even more evident in the top $25 \mathrm{~m}$, which coincided 
with the upper thermocline (CHIODINI et alii, 2012). The negative DICT fluxes for the top $10 \mathrm{~m}$ likely reflects the absorption of $\mathrm{CO}_{2}$ from the air (Fig. 10b, c). Focused, high-resolution surveys should detail whether this $\mathrm{CO}_{2}$ absorption from air increases -slightly apparent when comparing Fig. 10a and $\mathrm{b}$, is a side-effect of global warming. The effect of climate change on the Lago Albano degassing will be a focus of future studies.

Figure 10c shows the general decreasing trend in the DICT flux from bottom to top for the entire three decades of observation (1989-2019). As water layers become more voluminous towards the top, the diffuse degassing mechanism will be facilitated towards the shallower strata due to a higher concentration gradient. Nevertheless, the effect of the lake level drop during the past 30 years, and the resulting instability in the lake stratification, influences the degassing regime. Figure 11a shows the variation in terms of DICT fluxes, assuming an invariable lake level and volume. Comparing Fig. 11a with Fig. 10c, it is clear that DICT fluxes are more stable when the lake volume and stratification are remaining stable. Excessive well pumping from the Ciampino Plain aquifer for anthropic purposes does not only lead to water loss out of Lago Albano (MAzza et alii, 2015), but could also negatively affect the $\mathrm{CO}_{2}$ degassing from the lake, for becoming less stable and hence potentially more hazardous in the future.

We note near-zero DICT fluxes for any stratum calculated for the 2019 survey for the period May 2010-April 2019 (Fig. 11b). This observation could imply that (1) the $\mathrm{CO}_{2}$ degassing has effectively reached steadystate conditions, leading to very low or absent $\mathrm{CO}_{2}$ release from Lago Albano in the future, despite being not fully $\mathrm{CO}_{2}$-free, or (2) the period of observation is too long resulting in smoothened calculated $\mathrm{Q}_{\text {DIст }}$ values. The former hypothesis suggests that the self-lifting process of $\mathrm{CO}_{2}$ degassing, which also maintained the artificial $\mathrm{CO}_{2}$ degassing at Lake Nyos through the degassing pipes (Kusakabe, 2017; Halbwachs et alii, 2020, and references therein), might be interrupted because of the too-low gas pressure and concentration gradient between strata to persistently carry the gas upwards. Unfortunately, for the period May 2010-April 2019 no published data are available to provide insights on when exactly the steadystate dynamics might have started. In terms of hazard assessment, this means that Lago Albano will hardly ever be $\mathrm{CO}_{2}$-free and that gas bursts can occur if a sudden, additional and voluminous co-seismic $\mathrm{CO}_{2}$ recharge takes place.

As discussed by Rouwet et alii (2019), Lago Albano has a relatively low "depth ratio" ( $D R=0.45$, see equation (1)), because the surface area (S) is large with respect to the volume $(\mathrm{V})$, and the maximum lake depth $\left(\mathrm{d}_{\max }\right)$ is high. As observed here and in earlier studies (CIONI et alii, 2003; CARAPEZza et alii, 2008; CHIODINI et alii, 2012; CABASSI et alii, 2013), the lake is clearly stratified in its deepest parts. On the total lake scale, Lago Albano has a relatively low tendency to stratify (compared to e.g. Lake Nyos, DR = 0.55) due to the presence of two nested craters with broad flat floors. The "exotic" morphology of the lake basin apparently causes the particular syphon-like degassing style and spatiotemporal dynamics presented in the degassing model for the past 30 years.
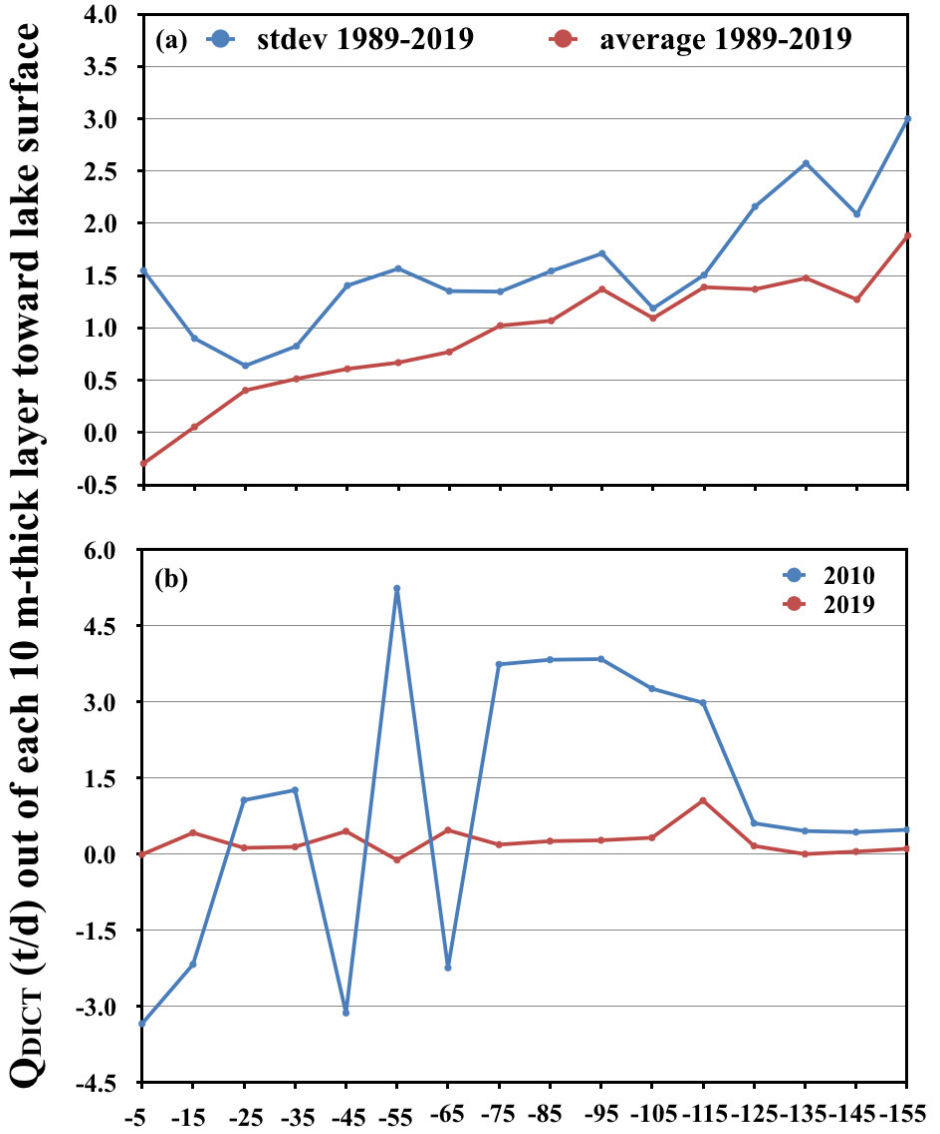

lake depth (m)

Fig. 11 - (a) The average $\mathrm{Q}_{\text {DICT }}$ and their standard deviation for the entire period of observation, without considering the $6.1 \mathrm{~m}$-lake level drop and corresponding volume changes in lake strata. Compared to Fig. 10c the $Q_{\text {DICT }}$ is clearly less variable for a constant lake volume, directly reflecting the impact of massive well pumping from the Ciampino Plain aquifer on the degassing dynamics of Lago Albano. (b) The $\mathrm{Q}_{\text {DICT }}$ reaches near-zero values in 2019, suggesting the limit of the gas self-lifting process, and hence the attainment of steady-state conditions of DICT fluxes among lake strata.

\section{CONCLUDING REMARKS}

This study presents the first published geochemical survey for the volcanic lake of Lago Albano, Rome, after a hiatus of almost nine years. Within our expectations, the trend in evolving $\mathrm{CO}_{2}$ degassing, after the gas recharge coincident with the 1989-1990 seismic crisis below the Colli Albani volcano, has continued; moreover, the 20162017 major tectonic earthquakes in Central Italy did not seem to have affected the degassing dynamics of Lago Albano, regarding gas input, nor output.

To revise the long-term degassing model (CHIODINI et alii, 2012), a DIC budget analysis reveals how each lake stratum, at $10 \mathrm{~m}$ intervals, has released DIC - and hence $\mathrm{CO}_{2}-$ to the stratum above, expressed as fluxes. The morphology of the lake basin seems to influence the degassing dynamics and DIC distribution among lake strata. The results of the 2019 surveys suggest that $\mathrm{CO}_{2}$ degassing has reached steadystate conditions, demonstrated by near-zero fluxes between strata. This implies that Lago Albano is probably unable to fully degas, due to the limit of the gas self-lifting process, to 
become a $\mathrm{CO}_{2}$-free lake in the future, with implications for the next co-seismic gas reloading of Lago Albano: notably higher $\mathrm{CO}_{2}$ fluxes from deep strata were estimated for 5-6 years after 1989-1990, arguably explaining the sudden degassing events concurrent with the seismic crises in the $19^{\text {th }}$ century (RouweT et alii, 2019), and thus potentially future events.

The DIC budget analysis also considers the lake level drop (approx. $6.1 \mathrm{~m}$ ) and resulting volume decrease (approx. $3.3 \times 10^{7} \mathrm{~m}^{3}$ ) of Lago Albano, observed for the period 1989-2019, due to the massive well pumping from the Ciampino Plain aquifers. This anthropic stress factor appears to have a destabilizing effect on the lake stratification and $\mathrm{CO}_{2}$ degassing dynamics on the long term. Moreover, $\mathrm{CO}_{2}$ absorption at the lake surface has apparently increased during more recent years; this can be caused by the higher $\mathrm{CO}_{2}$ contents in the air during times of global warming, and can hence further increase in the future. Both external effects (i.e. well pumping and global warming) on the lake's limnology and geogenic $\mathrm{CO}_{2}$ degassing need further investigations, applying finer spatial and high-frequency temporal geochemical and geophysical surveys. We suggest to verify whether the general assumption of horizontal homogeneity (for Lago Albano and other $\mathrm{CO}_{2}$-laden volcanic lakes) effectively counts, as small-scale features, such as $\mathrm{CO}_{2}$-rich vents or carbonate mineral sinks, could influence the degassing regime and $\mathrm{CO}_{2}$ budget of volcanic lakes. The infra-red ProOceanus Mini-CO $\mathrm{CO}_{2}$ probe here applied for the first time, is a promising tool for such high frequency (i.e. time) and high resolution (i.e. space) surveys.

\section{ACKNOWLEDGMENTS}

We are grateful to Federico Bronzi and Stefano Cresta (Parco Regionale Castelli Romani) for the permissions and invaluable logistic support on the lake. This study was funded by CALAPA-FISR 2016 (2018-2019). We dedicate this study to Prof. Mariano Valenza for his lifelong dedication to fluid geochemistry -and especially $\mathrm{CO}_{2}$ degassing-and for being a Master to us and many of our peers. Minoru Kusakabe and Artur Ionescu are thanked for their subtle comments that fine-tuned this study. The Special Issue editors are thanked for receiving and handling our MS.

\section{REFERENCES}

Amato A., Chiarabba C., Cocco M., Di Bona M. \& Selvaggi G. (1994) - The 1989-1990 seismic swarm in the Alban Hills volcanic area, central Italy. J. Volcanol. Geotherm. Res., 61, 26-37.

Anzidei M, Carapezza M.L., Esposito A., Giordano G., Lelli M. \& Tarchin L. (2008) - The Albano Maar Lake high resolution bathymetry and dissolved $\mathrm{CO}_{2}$ budget (Colli Albani volcano, Italy): Constrains to hazard evaluation. J. Volcanol. Geotherm. Res., 171, 258-268.

Cabassi J., Capecchiacci F., Magi F., Vaselli O., Tassi F., Montalvo F., Esquivel I., Grassa F. \& CAPRAI A. (2019) - Water and dissolved gas geochemistry at Coatepeque, Ilopango and Chanmico volcanic lakes (El Salvador, Central America). J. Volcanol. Geotherm. Res., 378, $1-15$.

Cabassi J., Tassi F., Vaselli O., Fiebig J., Nocentini M., Capecchiacci F., Rouwet D. \& Bicocchi G. (2013) - Biogeochemical processes involving dissolved $\mathrm{CO}_{2}$ and $\mathrm{CH}_{4}$ at Albano, Averno, Monticchio meromictic volcanic lakes (Central-Southern Italy). Bull. Volcanol., 75, 683.

Caliro S., Chiodini G., Izzo G., Minopoli C., Signorini A, Avino R. \& GRANIERI D. (2008) - Geochemical and biochemical evidence of lake overturn and fish kill at Lake Averno, Italy. J. Volcanol. Geotherm. Res., 178, 305-316.
Capasso G., Favara R., Grassa F., Inguaggiato S. \& Longo M. (2005) - On-line technique for preparing and measuring stable carbon isotope of total dissolved inorganic carbon in water samples $\left(\delta^{13} C\right.$ TDIC). Ann. Geophys., 48, 159-166.

Carapezza M.L. \& TARChini L. (2007) - Magmatic degassing of the Alban Hills volcano (Rome, Italy): geochemical evidence from accidental gas emission from shallow pressurized aquifers. J. Volcanol. Geotherm. Res., 165, 5-16.

Carapezza M.L., Badalamenti B., Cavarra L. \& Scalzo A. (2003) - Gas hazard assessment in a densely inhabited area of Colli Albani Volcano (Cava dei Selci, Roma). J. Volcanol. Geotherm. Res., 123, 81-94.

Carapezza M.L., Lelli M. \&, TARchini L. (2008) - Geochemistry of the Albano and Nemi crater lakes in the volcanic district of Alban Hills (Rome, Italy). J. Volcanol. Geotherm. Res., 178, 297-304.

CHIODINI G. (1996) - Gases dissolved in groundwaters: analytical methods and examples of applications in central Italy. L. Marini, G. Ottonello (Eds.), Rome Seminar on Environmental Geochemistry. Pacini Editore, Castelnuovo d Porto, Rome (Italy) (1996), pp. 135-148.

Chiodini G., Cioni R., Guidi M., Raco B. \& Marini L. (1998) - Soil $\mathrm{CO}_{2}$ flux measurements in volcanic and geothermal areas. Appl. Geochem., 13, 543-552.

Chiodini G. \& Frondini F. (2001) - Carbon dioxide degassing from the Alban Hills volcanic region, Central Italy. Chem. Geol., 177, 67-83

Chiodini G., Tassi F., Caliro S., Chiarabba C., Vaselli O., Rouwet D. (2012) - Time-dependent $\mathrm{CO}_{2}$ variations in Lake Albano associated with seismic activity. Bull. Volcanol., 74, 861-871. https://doi. org/10.1007/s00445-011-0573-X

Cioni R., Guidi M. Raco B, Marini L \& Gambardella B. (2003) - Water chemistry of Lake Albano (Italy). J. Volcanol. Geotherm. Res. 120, 179-195.

Evans W.C., Kling G.W., Tuttle M.L. \& Tanyileke G. (1993) - Gas buildup in Lake Nyos, Cameroon: the recharge process and its consequences. Appl. Geochem., 8, 207-221.

Freda C., Gaeta M., Karner D., Marra F., Renne P.R., Taddeucci J. Scarlato P., Christensen J.N. \& Dallai L. (2006) - Eruptive history and petrologic evolution of the Albano multiple maar (Alban Hills, Central Italy). Bull. Volcanol., 68, 567-591.

Funiciello R., Giordano G. \& De Rita D. (2003) - The Albano maar lake (Colli Albani Volcano Italy): recent volcanic activity and evidence of pre-Roman Age catastrophic lahar events. J. Volcanol. Geotherm. Res., 123, 43-46.

Funiciello R., Giordano G., De Rita D., Carapezza M.L., Barberi F. (2002) - L'attività recente del cratere del Lago Albano di Castelgandolfo. Rend. Acc. Lincei, 9-13, 113-143.

Giordano G., De Benedetti A., Diana A., Diano G., Gaudioso F., Marasco F., Miceli M., Mollo S., Cas R.A.F. \& Funiciello R. (2006) - The Colli Albani mafic caldera (Roma, Italy): stratigraphy, structure and petrology. J. Volcanol. Geotherm. Res., 155, 49-80.

Halbwachs M., Sabroux J-C \& Kayser G. (2020) - Final step of the 32 year Lake Nyos degassing adventure: Natural $\mathrm{CO}_{2}$ recharge is to be balanced by discharge through the degassing pipes. J. Afric. Earth Sci., 167, 103575. https://doi.org/10.1016/j.jafrearsci.2019.103575

Inguaggiato S \& Rizzo A.L. (2004) - Dissolved helium isotope ratios in ground-waters: A new technique based on gas-water re-equilibration and its application to Stromboli volcanic system. Appl. Geochem., 19, 665-673.

Kling G.W., M.A. Clark, Wagner G.N. \& Koenigsberg E.J. (1987) - The 1986 Lake Nyos Gas Disaster in Cameroon, West Africa. Science, 236, 169-75.

KusaKabe M. (2015) - Evolution of $\mathrm{CO}_{2}$ content in Lakes Nyos and Monoun, and sub-lacustrine CO-recharge sys-tem at Lake Nyos as envisaged from $\mathrm{CO}_{2}{ }^{3} \mathrm{He}$ ratios and noble gas signatures. In: Rouwet D., Christenson B., Tassi F. \& Vandemeulebrouck J. (Eds.), Volcanic Lakes., 427-450, Springer-Verlag, Berlin, Heidelberg. https://doi.org/10.1007/978-3-642-36833-2 19

KusaKabe M. (2017) - Lakes Nyos and Monoun Gas Disasters (Cameroon) - Limnic Eruptions Caused by Excessive Accumulation of Magmatic $\mathrm{CO}_{2}$ in Crater Lakes. Geochem. Monogr. Series, 1, $1-50$.

Marra F., Castellano C., Cucci L., Florindo F., Gaeta M., Jicha B.R., Palladino D.M., Sottili G., Tertulliani A. \& Tolomeo C. (2020) Monti Sabatini and Colli Albani: the dormant twin volcanoes at the gates of Rome. Nature Scientific Reports, 10, 8666. https://doi. org/10.1038/s41598-020-65394-2 
Martelli M., Nuccio P.M., Stuart F.M., Burgess R., Ellam R.M. \& ITALIANO F. (2004) - Helium-strontium isotope constraints on mantle evolution beneath the Roman Comagmatic Province, Italy. Earth Planet. Sci. Lett., 224, 295-308.

Martini M., Giannini L., Prati F., Tassi F., Capaccioni B. \& Iozzelli, P. (1994) - Chemical characters of crater lakes in the Azores and Italy: the anomaly of Lake Albano. Geochem. J., 28, 173-184.

Mazot A., Rouwet D., Taran Y., Inguaggiato S. \& Varley N. (2011) $\mathrm{CO}_{2}$ and He degassing at El Chichón volcano, Chiapas, Mexico: gas flux, origin and relationship with local and regional tectonics. Bull. Volcanol., 73, 423-441. https://doi.org/10.1007/s00445-010-0443-y

Mazza R., La Vigna F., Capelli G., Dimasi M., Mancini M. \& Mastrorillo L. (2016) - Idrogeologia del territorio di Roma. It. J. Groundwater. 4(4). https://doi.org/10.7343/as-129-15-0156

Pérez N.M., Hernández P.A., Padilla G., Nolascoo D., Barrancos J. Melíán G., Padrón E., Dionis S., Calvo D., Rodríguez F., Notsu K. Mori T., Kusakabe M., Arpa C.M., Reniva P. \& Ibarra M. (2011) Global $\mathrm{CO}_{2}$ emission from volcanic lakes. Geology, 39(3). https:// doi.org/10.1130/G31586.1

Pedreschi L. (1995) - I centri lacuali della penisola italiana. III: I centri dei laghi vulcanici di Castel Gandolfo e di Nemi e quelli dei bacini artificiali. Accademia Lucchese di Scienze, Lettere ed Arti, Studi e testi, Lucca, 39, 136 pp.

Rounet D., Chiodini G., Ciuccarelli C., Comastri A. \& Costa A. (2019) - Lago Albano, the "anti-Nyos-type" lake: The past as a key for the future. J. Afric. Earth Sci., 150, 425-440.
SANO Y. \& H. WAKITA (1985) - Geographical distribution of ${ }^{3} \mathrm{He} /{ }^{4} \mathrm{He}$ ratios in Japan: Implications for arc tectonics and incipient magmatism. J. Geophys. Res., 90, 8729-8741.

Tanyileke G., Ntchantcho R., Fantong W.Y., Aka F.T. \& Hell J.V. (2019) - 30 Years of the Lakes Nyos and Monoun Gas Disasters: A scientific, technological, institutional and social adventure. J. Afric. Earth Sci., 150, 415-424.

TAssi F. \& Rouwet D. (2014) - Geochemical studies of Nyos-type lakes: different approaches for data production and interpretation. An overview. J. Limnol., 73, 39-54.

Tassi F., Vaselli O., Tedesco D., Montegrossi G., Darrah T., Cuoco E., Mapendano M.Y., Poreda R., \& Delgado Huertas A. (2009) - Water and gas chemistry at Lake Kivu (DRC): geochemical evidence of vertical and horizontal heterogeneities in a multibasin structure. Geochem. Geophys. Geosyst., 10(2). https://doi. org/10.1029/2008GC002191

Trigila R. (Ed.) (1995) - The volcano of the Alban Hills. Tipografia SGS, Rome (1995), 283 pp.

Venturi S., Tassi F., Cabassi J., Vaselli O., Minardi I., Neri S., Caponi C., Capasso G., Di Martino R.M.R., Ricci A., Capecchiacci F., Lelli M., Sciarra A., Cinti D. \& Virgili G. (2019) - A multi-instrumental geochemical approach to assess the environmental impact of $\mathrm{CO}_{2}$ rich gas emissions in a densely populated area: The case of Cava dei Selci (Latium, Italy). Appl. Geochem., 101, 109-126. https://doi. org/10.1016/j.apgeochem.2019.01.003 